\title{
Una visión calvinista de los conceptos clásicos de amor y belleza
}

\author{
Amparo López Redondo y Jose M. ${ }^{\text {a Martín ÉcluA* }}$
}

\begin{abstract}
RESUMEN
ABSTRACT

Este artículo presenta un estudio

iconográfico de las pinturas que decoran un escritorio holandés de la primera mitad del siglo XVII, conservado

en el Museo Lázarc Galdiano de

Madrid, planteándolo como una ilustración pictórica de los conceptos clásicos de amor y belleza desde una visión moral protestante y en concreto calvinista de los mismos.

En él se presentan parte de las fuentes

de inspiración literaria y también pictórica en las ilustraciones de Virgilio

Solís realizadas para una edición antuerpiense de 1598 de las Metamorfosis de Ovidio.

Establece así mismo un nexo comparativo con otros dos escritorios de igual procedencia, uno de ellos conservado en el Museo de Artes Decorativas de Madrid y otro subastado por la casa Bonhams en Londres.

This article consists of an iconographic analysis of the paintings in a Dutch writing desk that dates from the first half of the $17^{\text {th }}$ century and which is found in the collection of the Museo Lazaro Galdiano of Madrid. I propose that these paintings illustrate the classical ideals of love and beauty from a moralistic and Protestant, more specifically Calvinist, position.

Somo of its literary as well as pictorial sources include the Antwerp edition by Virgilio Solis of Ovid's Metamorphosis, published in 1698.

In addition, the desk will be compared to two other similar pieces also of Dutch provenance: one is found in the Museo de Artes Decorativas of Madrid and the other appeared at an auction of Bonhams in London.
\end{abstract}




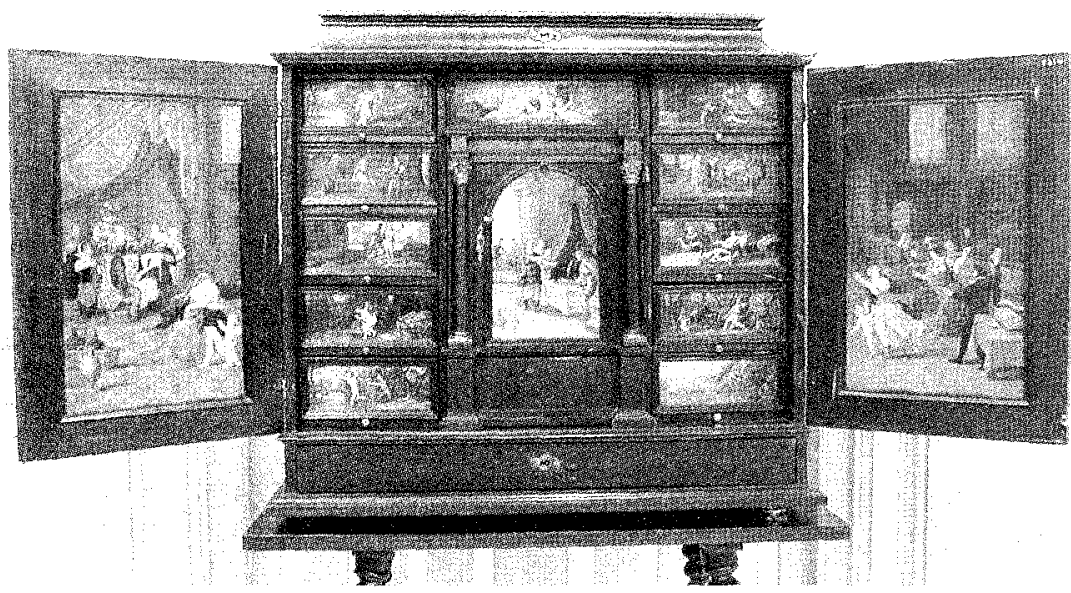

Fig. 1.

El Museo Lázaro Galdiano custodia entre sus colecciones un escritorio con bellísima decoración pictórica, muy probablemente realizado en Amberes en torno a mediados del siglo XVII. Este artículo pretende desentrañar su complejo discurso iconográfico, que presenta un caleidoscopio de valores morales de acendradas raíces filosóficas, políticas y religiosas vigentes en la Europa del momento.

Los motivos centrales en torno a los que gira este hermoso mueble son el amor, la belleza, el alma y su consideración moral y filosófica. La concepción estética es manierista y por ello se recurre a la representación pictórica de los mitos clásicos como medio de expresión de ideas y valores conceptuales. Es decir: se vuelve la mirada a los mitos clásicos y se construye con ellos un sistema de símbolos, que dota a la pintura de una capacidad filosófica y narrativa semejante a la de la poesía, retomando con ello la idea clásica ut pictura poesis. De este modo, el manierismo crea un lenguaje simbólico que retoma los mitos como explicación de los poderes organizativos del universo y los traslada a la concepción cristiana del mundo.

Esta concepción artística tiene sus raíces en el neoplatonismo literario desarrollado a partir del siglo xv en la Academia creada por Marcilio Ficino en Florencia, una comunidad espiritual que acomete la interpretación de los poetas de la Antigüedad y de los mitos clásicos. La obra fundamental de Ficino, De Amore: comentario al Banquete de Platón, ejerce una gran influencia filosófica en la concepción estética del siglo XVI y se encuentra en parte de la representación que nos ocupa, como veremos. 
Pensamos que éstas son las claves interpretativas de este escritorio de concepción puramente intelectual que se nos presenta como un fascinante galimatías cuyo discurso no es posible comprender fuera de la concepción neoplatónica del arte y sin conocer la situación política y religiosa que atraviesa la Europa del momento, en plena Guerra de los treinta años.

Pretendemos aproximarnos a una interpretación de los motivos representados desde un instrumento fundamental para la documentación científica como es el estudio iconográfico e iconológico y aportar algo de luz sobre la autoría y otros aspectos que desconocemos, debido a la inexistencia de documentación alguna relativa a la procedencia de esta pieza en el Museo Lázaro. Es decir, estudiaremos la iconografía pretendiendo deducir para quien y por quien pudo ser realizada la obra.

En los Países Bajos, desde la segunda mitad del siglo XVI, se fabrica para su comercialización un importante número de escritorios que poseen dos puertas y una serie de cajones dispuestos en tres registros de gavetas de desarrollo vertical. Suelen tener, como en este caso, un destacado espacio central en el que se coloca una puerta rematada en arco que imprime a la pieza un aspecto de fachada arquitectónica. Se fabrican normalmente en roble chapeado con molduras de ébano, frecuentemente se pintan y a veces, se decoran con carey. Las pinturas se realizan bien sobre planchas de cobre o bien sobre la madera. Son contadores derivados tipológicamente de modelos orientales y llegados a Europa a través de la Compañía de las Indias Orientales cuyo control comercial ostentan por entonces los Países Bajos.

La producción de estos escritorios sólo se explica a partir del importante desarrollo de una burguesía comercial y de una aristocracia cortesana que cambiará el mercado del arte al demandar nuevos objetos para uso y decoración de sus viviendas. Esta nueva clientela del arte es portadora de una ideología diferente a la regia y en ocasiones abraza opciones religiosas distintas a la católica. El cuadro de Hieronymus Janssen en la colección Liechtenstein ${ }^{1}$ nos muestra el ambiente que rodeaba a esta clientela, en él aparece uno de estos cabinet.

No resulta extraña la incorporación de temas mitológicos en estas papeleras, sin embargo, son también frecuentes numerosas temáticas como la cristiana, floral, animal, arquitectónica o escultórica. En cuanto al primer caso, mencionaremos el decorado por el importante pintor flamenco Frans Francken II y conservado en el Rijksmuseum de Amsterdam repre-

1 Thornton, Peter, 1983, pág. 253, fig. 241. 
sentando escenas del Génesis que presenta similitudes tipológicas con el del Museo Lázaro.

En el Museo de Artes Decorativas de Madrid se conserva otro escritorio con escenas mitológicas tomadas en su mayoría, como en el del Lázaro Galdiano, de Las Metamorfosis de Ovidio, que nos servirá para establecer una interpretación comparativa más adelante.

Monique Ricardi-Cubbit recoge un interesante grupo de estos escritorios realizados en Amberes en torno a mediados del siglo XVII, uno de los cuales formó parte de la colección del Archiduque Leopoldo y se encuentra hoy en el Museo de Bellas Artes de Viena. De entre los que esta estudiosa recoge hay uno que fue subastado por la casa Bonhams de Londres cuyas puertas tienen una decoración muy semejante al del Lázaro Galdiano. Desafortunadamente todos los intentos que hemos realizado para conocer algo más sobre esta obra han sido infructuosos. ${ }^{2}$

\section{INTERPRETACIÓN DE LA DECORACIÓN PICTÓRICA}

Podemos diferenciar dos tipos de representaciones en el escritorio del Museo Lázaro Galdiano aunque ambas se encuentran integradas en un mismo discurso narrativo: por una parte las reflejadas en las puertas que cierran el mueble y por otra las que aparecen en el frontal de los cajones. No sólo se trata de una diferencia de tamaño y calidad sino también de concepción temática. Las puertas escenifican alegorías de fundamento filosófico y religioso, mientras los cajones ilustran narraciones literarias tomadas de Las Metamorfosis de Ovidio.

El punto de partida es la puerta de la izquierda, en su ángulo inferior derecho se representa el abrazo entre dos personajes femeninos que interpretamos como el Aima cristiana y la Belleza figurados como Psique y Venus respectivamente, ocurriendo esto en presencia del Amor que afina su puntería con una flecha en la mano en una actitud distinta a la habitual del dios caprichoso que dispara sus flechas al azar. Este abrazo entre el Alma y la Venus celeste es una ilustración en imágenes de la parte del discurso platónico y ficiniano en la que se indica el poder de atracción de la Belleza sobre el Alma: "Y la Belleza es un resplandor que atrae a si al espíritu humano" ${ }^{3}$.

\footnotetext{
Ricardi Cubitt, Monique, 1993, págs. 47-97

FiclNo, Marsilio, 1986, pág. 47
} 


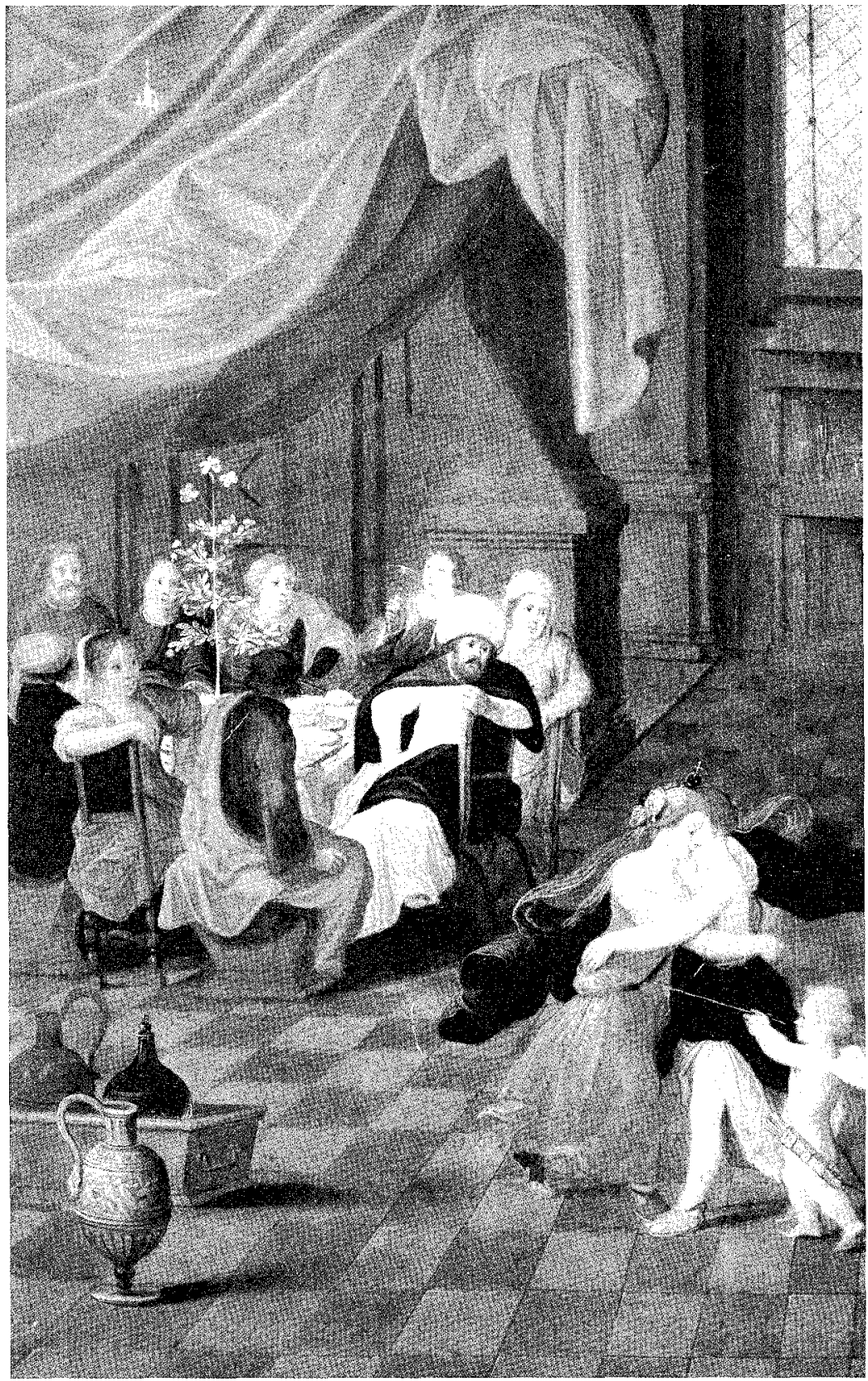

Fig. 2. 
El Alma aparece como una figura femenina ataviada con un velo transparente que simula unas alas divinas. En su tocado se vislumbra la figura de una mariposa que la identifica claramente con la doncella amante de Eros en El asno de oro de Apuleyo ${ }^{4}$. Sin embargo, el hecho de que Psique abrace a la Belleza y no al Amor nos indica que se trata del abrazo neoplatónico entre el Alma y la Belleza. Las alas. como dice Platón en el Fedro, le crecen al Alma por su encuentro con la Belleza: "Cuando un hombre percibe las bellezas de este mundo y recuerda la belleza verdadera su alma toma alas y desea volar" ${ }^{5}$. Las dos figuras femeninas están reunidas por el manto azul de la Venus celeste, el mismo que la identifica en el triunfo de Venus situado sobre la escena del Banquete de Tereo, y en la escena de Venus y Marte; Psique está coronada por la Imago Mundi que nos remite al carácter universal de las alegorías, o tal vez establece una referencia a la Iglesia de Cristo.

El abrazo entre las dos figuras se realiza, como decíamos, en presencia del Amor que indica el camino con su flecha y conecta a ambas, pues "el amor es el deseo de gozar de la Belleza" ${ }^{6}$. Cuando hablamos de la Belleza nos referimos a la Belleza de Dios; como dice Pedro R. Santidrián, "Ficino en su comentario al Fedro nos dirá que el amor de que habla Platón y del que habla San Pedro son uno y el mismo: el amor

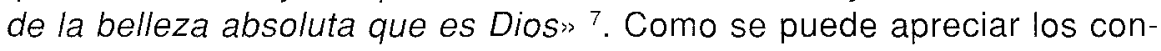
ceptos y las relaciones entre la Belleza, el Alma y el Amor en las obras de Platón y Ficino son muy semejantes, la diferencia fundamental estriba en que para Ficino la Belleza y el Bien Absoluto es el Dios cristiano lo que no es así para Platón. Por otra parte, tanto Ficino como nuestro artista hacen una lectura monoteísta de los mitos de la Antigüedad y es así como se explica que la figura de Venus en este abrazo pueda simbolizar la Belleza Absoluta de Dios. El Alma evita los placeres del amor sensual y busca la virtud y la belleza, por lo que llega a reunirse con la divinidad: «Porque la ley divina no permite que los que han comenzado su viaje celeste sean precipitados en las tinieblas subterráneas, sino que pasan una vida brillante y dichosa en eterna unión, y cuando reciben alas, las obtienen juntos, a causa del amor que les ha unido sobre la tierra" 8 .

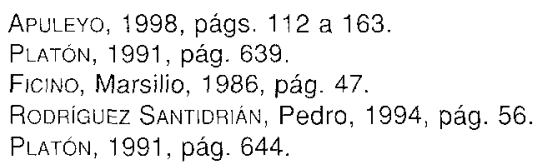


Este abrazo entre el Alma y la Belleza donde está presente el Amor, es contemplado atentamente por un grupo de nueve comensales reunidos en torno a una mesa, en cuyo centro florece una vara, que parece un granado. Este es el símbolo de Proserpina y de la resurrección para los cristianos ${ }^{9}$. También es el de la Iglesia por su carácter de unidad en la multiplicidad de su fruto.

Este banquete podría, tal vez, ser una referencia al Banquete de Platón donde se debate sobre diferentes características del amor mundano que podríamos encontrar presentes en las gavetas. Esta interpretación se vislumbraba someramente en el artículo de Casto Castellanos ${ }^{10}$ publicado en la Revista Goya.

Entre los comensales sorprende la presencia de una serie de mujeres que resultaría impensable en un banquete de la Antigüedad. Muy por el contrario nos encontramos ante un banquete contemporáneo al de nuestro artista, de la primera mitad del S. XVII, como lo evidencian el mobiliario, la vajilla y la indumentaria de los personajes. Esto nos indica que estamos ante una actualización del discurso platónico y de su retórica en forma de diálogos. En concreto vemos una referencia al diálogo platónico El Banquete o del Amor donde los comensales se proponen hacer un elogio del amor del que resulta la discriminación de un Amor celeste (Uranio) y de otro vulgar (Pandemo) según el discurso de Pausanias ${ }^{11}$, la misma diferenciación parece establecer el artífice del contador del Lázaro. En Platón la Belleza y el Amor van indisolublemente unidos como el motivo y la acción de la inclinación del alma y del cuerpo, de ahí que este grupo de figuras nos remita al autor de los Diálogos. Sócrates entiende el Amor a partir de la definición que le da Diotima como un «gran genio, (...) porque todo lo que es genio está entre lo divino y lo mortal (...) interpreta y transmite a los dioses las cosas humanas y a los hombres las cosas divinas, las súplicas y los sacrificios de los unos y las órdenes y las recompensas a los sacrificios de los otros. Colocado entre unos y otros rellena el hueco, de manera que el Todo queda ligado consigo mismo.» ${ }^{12}$. El abrazo

«Proserpina (...) corresponde (...) al resurgir de la vida», AGHION, I. et al., 1997, pág. 298. CASTEllanos; Casto Goya 1986 193-5 pág. 150.

«Todos sabemos que no hay Afrodita sin Amor. En el caso, pues de que fuera única habría tan solo un amor, pero como existen dos necesariamente habrá dos amores. ¿Y como negar que son dos las diosas? Una de ellas la mayor probablemente, no tuvo madre y es hija de Urano (el Cielo), por lo cual le damos el nombre de Urania (Celeste); la otra, la más joven es hija de Zeus y de Dione y la llamamos Pandemo (Vulgar). De ahi que sea necesario también llamar con propiedad al Amor que colabora con esta ultima Pandemo (Vulgar) y al otro Uranio (Celeste).» PLATón 1982, pág. 15.

12 Platón, 1982, pág. 45. 
anteriormente descrito resultaría una transposición de otro diálogo platónico: Fedro o del Amor.

En este banquete destaca una figura vestida a la oriental, tal vez una referencia política, mientras en el otro extremo de la mesa aparece un hombre que podría ser el mismo Sócrates, dado su parecido físico y su situación en la mesa de debate, similar a la que ocupa Sócrates en el Banquete.

En el ángulo inferior izquierdo de esta imagen aparecen tres vasijas cuya disposición reproduce fielmente la del grupo de Venus, incluso dos de éstas están integradas en un recipiente situados a la misma altura que el abrazo de Venus y Psique. La vasija del primer plano presenta una decoración donde reconocemos el friso del altar de Zeus en Pérgamo representando la Gigantomaquia "que recuerda la supremacía de los dioses»"13. La soberbia de los gigantes les hace enfrentarse a los dioses olímpicos para alcanzar el cielo según refiere Ovidio en el libro I de Las Metamorfosis, el uso de estas figuras aquí, pensamos que es una referencia semejante a la que se ha querido ver en el Palacio Te de Mantua de Giulio Romano, en esta ocasión la referencia sería a la Guerra de los treinta años y al enfrentamiento entre católicos y protestantes.

La puerta de la derecha presenta una temática menos complicada y de más fácil interpretación: se trata de la expulsión del vicio por Minerva y otros tres personajes. Minerva «encarna a la vez la prudencia y la sabiduría ${ }^{14}$, por lo que es el paradigma de la virtud y así aparece representada en ocasiones expulsando a los vicios como en la obra de Mantegna «El triunfo de la virtud» conservada en el Louvre. En el mueble del Lázaro, Minerva aparece acompañada por tres figuras que expulsan a la Belleza conducida por el Amor mundano arrojándoles libros, una de ellas parece identificarse con Calvino. Minerva y otro de los personajes esgrimen una lanza y un cetro respectivamente. La palabra escrita empleada como arma y el uso de la fuerza son referencias a la convulsión bélica que agita Europa en la llamada Guerra de los Treinta Años que enfrenta a católicos y protestantes, y a la justificación de la fuerza como medio para mantener la fe: "¿Qué otra cosa es la guerra, sino el castigo de la injusticia y del mal? ¿Por qué se hace una guerra, sino para conseguir la paz y la obediencia?» ${ }^{15}$.

\footnotetext{
Aghion, l. et al., 1997, págs. 169-170.

Aghion, l. et al., 1997, pág. 237.

Lutero, Martín, 1990, pág. 130.
} 


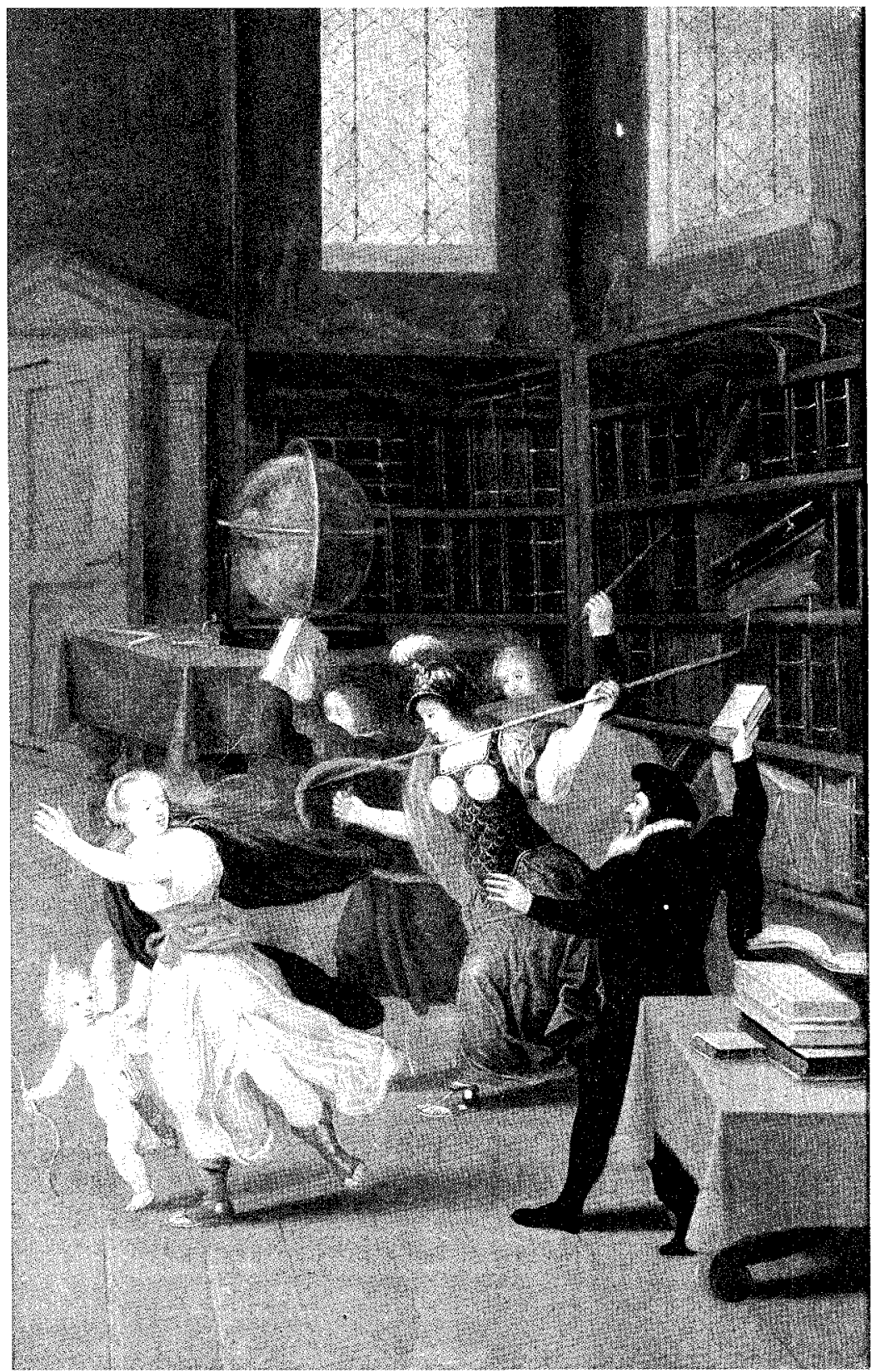

Fig. 3. 
La figura del ángulo inferior derecho vestida de negro presenta un gran parecido con el protestante Calvino. El calvinismo, en mayor medida que el luteranismo, es el movimiento religioso que explica en parte el conflicto en los Países Bajos. De tratarse de la figura de Calvino como parece evidente el discurso pictórico concluiría con este personaje y en cierto modo ilustraría la concepción calvinista sobre las Sagradas Escrituras, de acuerdo con lo que se señala en la Institutio Christianae Religionis, obra que recoge toda su doctrina: "Lo que el hombre por si solo puede decir acerca de Dios y de los hombres es una locura, solo se es teólogo cuando uno se deja instruir por el propio Dios en la Sagrada Escritura. Nadie llega al más mínimo entendimiento de la doctrina recta y salvífica, si previamente no se hace discípulo de las Sagradas Escrituras» ${ }^{15}$.

En este sentido entenderíamos que existe un complejísimo sistema de valores reflejado en el escritorio que permitiría una doble lectura, por un lado una interpretación neoplatónica en la que encontraríamos referencias a las obras de Platón: El Banquete, Fedro, y La República; por otro una interpretación religiosa en la que se aboga por el Calvinismo y se condena la corrupción de la Iglesia Católica y el pecado encarnado en Las Metamorfosis de Ovidio presentadas en la cajonería. Bien podría interpretarse el conjunto de las representaciones como una afirmación del calvinismo, represor de los vicios y guardián en consecuencia de la virtud, frente al resto de las religiones, en especial la católica, que aceptan en su regazo a los vícios. Así podríamos interpretar el abrazo entre Venus y Psique de la puerta izquierda como una burla del pensamiento ficiniano-platónico y la figura vestida a la turca como representativa de la religión islámica que asiste al banquete que es el mundo. La gigantomaquia que aparece en el jarrón en primer término nos hablaría de la lucha entre dos concepciones del mundo diferentes, y mientras en el Palacio Te de Mantua, Giulio Romano simboliza el triunfo de Carlos $V$ sobre los príncipes alemanes, en este caso aludiría a la Guerra de los Treinta Años, en la esperanza de que se reafirme la supremacía de los dioses en detrimento de los viciosos Papas católicos. Nos remite también de la soberbia de estos últimos que, como los gigantes, pretendian acaparar funciones de los dioses como las de las indulgencias o el perdón.

De nuevo la alegoría se está empleando sincréticamente al integrar discursos de diferentes momentos históricos y distinta concepción filosófica

is Calyino, Juan, Institutio I, 6, 2. 
en uno solo. En este caso la referencia platónica no sólo viene dada por las figuras de la Belleza y del Amor profano sino también por diferentes conceptos recogidos en su diálogo La República o de 10 Justo. En esta obra Sócrates se propone dilucidar las características del Estado ideal guiado por la Justicia, para ello estudiará especialmente como debería ser la educación de sus ciudadanos, en concreto la de los guerreros, y el carácter que deberían tener.

En lo que se refiere al Amor vulgar, Platón dice en la República: «Por el contrario, o el amor conforme a razón es amor sensato y mesurado a 10 hermoso y honesto. - Así es - No hay que dejar, pues, que a este juicioso amor se llegue nada que tenga parte de furioso, de disoluto. -No-Por ende la voluptuosidad sensual no debe ser admitida en él, y aquellos que se amen con amor juicioso deberán desterrarla en absoluto de su trato» ${ }^{17}$. Por lo tanto Platón no toleraría en su Estado el amor sensual y lo expulsaría como sucede en esta pintura. Pero quizás el concepto platónico que mejor explica el discurso del mueble es el de "templanza» que "no es otra cosa que cierto orden, que un freno que ponemos a nuestros placeres y pasiones" ${ }^{18}$, es el concepto moral ideal para este filósofo y es la base de la ética de su Estado, también es una cualidad necesaria en el guerrero y un atributo de Minerva. No puede por tanto permitirse la entrada al templo de la sabiduría, que es una biblioteca, a los vicios.

Así mismo Calvino indica en una carta a la duquesa de Ferrara que se encuentra en el Corpus Reformatorum: "Os pido que tengáis mano firme por lo más supremo de nuestro poder, para establecer una severa disciplina que reprima los vicios y los escándalos." ${ }^{19}$

El gobernante que no se conduce por la templanza produce consecuencias desastrosas como ilustra dramáticamente el relato de Ovidio «Procne y Filomena» ${ }^{20}$ cuya representación aparece en la puerta central del escritorio al que es conducida nuestra mirada por el movimiento del grupo de los vicios de la puerta derecha ya comentado.

Un comentario de la obra de Ovidio del Licenciado Pedro Sánchez de Viana incluido en una edición de Las Metamorfosis de 1589 concluye en relación con el relato de Tereo: "La moralidad que los sabios antiguos

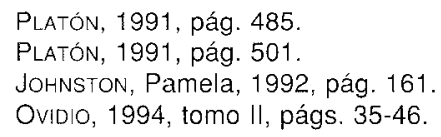


quisieron enseñar en esta fábula, es muy semejante a otras muchas antes de estas dichas, que los hombres buenos, virtuosos y prudentes deben vivir con mayor recato y sobresalto, para defenderse de las cosquillas y tentaciones de los deleites, que de las amenazas de los enemigos más feroces, pues ninguno lo es tanto como la destemplanza y luxuria, por cuya causa tantas muertes, $y$ destruyciones han succedido" ${ }^{21}$. Hemos señalado en el texto original la referencia a la destemplanza pero todo el sentido del texto en general coincide con el discurso platónico: el peligro de no ser dueño de sí mismo, de dejarse llevar por las pasiones. Y también Calvino dice en la Institutio: «Es muy dificil que los reyes se controlen tanto a si mismos que nunca entren en conflicto con lo justo y lo correcto; o que hayan sido dotados de tal prudencia y agudeza como para saber cuál es el limite. 22

En este sentido entendemos la escena que nuestro artista sitúa debajo del vértice que componen las figuras de Venus y Eros, que es, sin duda, una de las más trágicas de las metamorfosis.

La escena encarna, de la manera más cruel, las consecuencias que el amor mundano, el apetito desmedido, puede llegar a producir. Relatada por Ovidio en el libro VI 424-674, se trata de la historia de las hermanas Procne y Filomena hijas del ateniense Pandión. La primera se casó con el rey de Tracia Tereo, descendiente de Marte, que había auxiliado a Pandión en su lucha contra los tebanos, y marcho con él a Tracia, transcurrido un año y tras haber concebido a Itis, Procne ruega a su esposo que le permita volver a ver a su hermana Filomena, que él mismo se encargará de ir a buscar a la casa de su padre. Al verla dice Ovidio: "Tereo arde de pasión, como cuando alguien prende fuego a unas espigas secas o quema ramas y hierbas en el interior de un pajar. Sin duda el aspecto de ella es digno de tal reacción, pero además le incita un innato desenfreno, pues las gentes de aquellas regiones son particularmente inclines a la lujuria; asi pues, se inflama de un vicio propio de si mismo y también de su pueblo". Presa de esta inclinación, Tereo, tras conseguir persuadir a Pandión, logra llevarse a Filomena, y tras desembarcar en Tracia la viola, finalmente temiendo por su delación la corta la lengua y encierra en una cabaña. Filomena agudizará el ingenio para hacer llegar a su hermana el relato de sus desgracias en un paño bordado. Procne, enfurecida, la libera y juntas forjan una atroz

Ovibio, 1589, pág. Anotaciones sobre Ovidio 135.

Johnston, Pamela, 1992, pág. 162. 
Una visión calvinista de los conceptos clásicos de amor y belleza

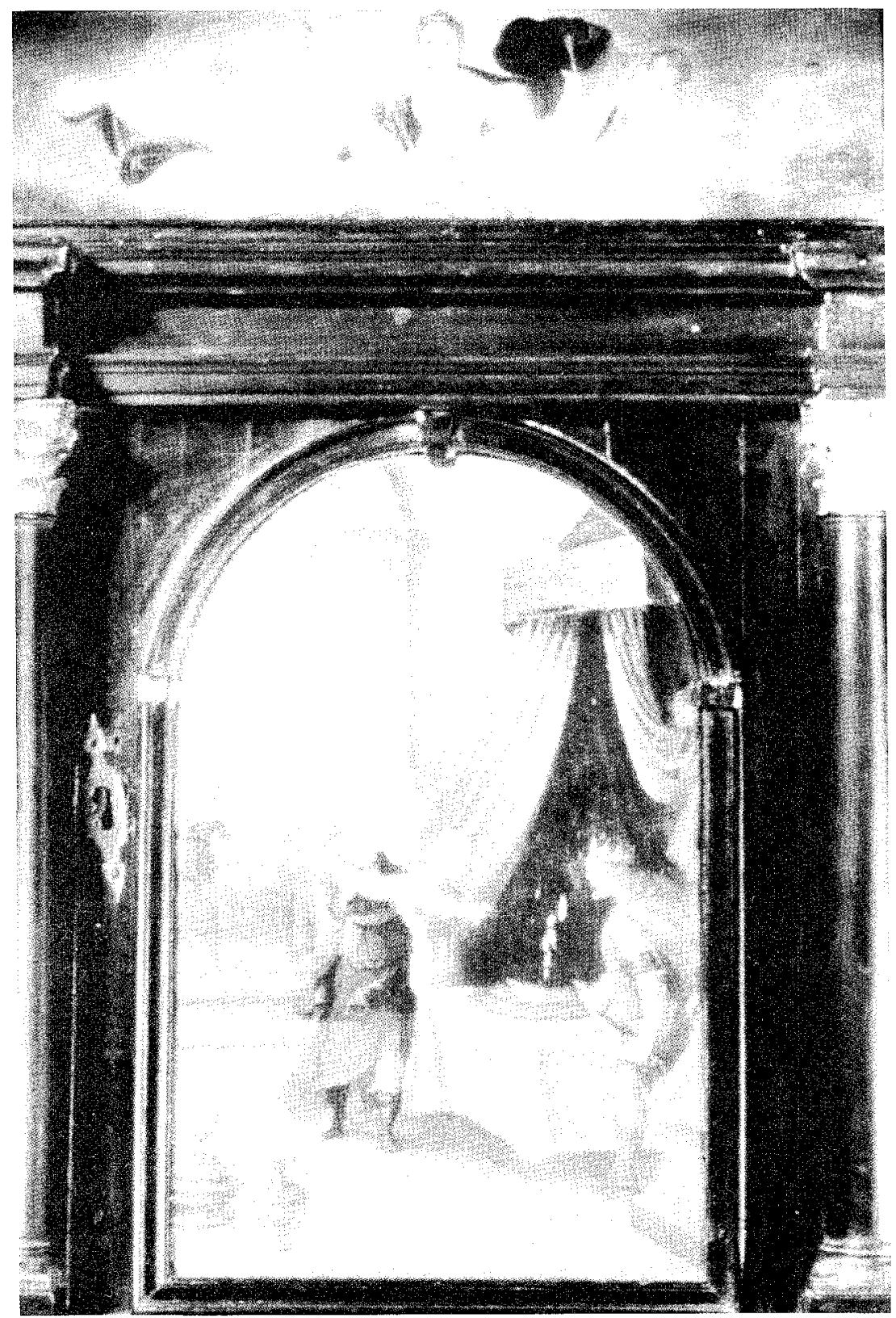

Fig. 4. 
venganza: descuartizarán al pobre hijo de ambos, Itis, que es ofrecido a su padre como exquisito manjar, y una vez ingerido éste, Tereo pide a Procne que traiga a su presencia a su amado hijo, ésta responde: « $L O$ que buscas lo tienes dentro (...). Filomena se planta ante él tal como está con los cabellos manchados por el furioso asesinato y arroja al rostro del padre la cabeza ensangrentada de Itis, (...)Tereo unas veces desea abrirse el pecho y sacar de alli esos funestos manjares, esas visceras que ha ingerido, otras veces llora y se lamenta a si mismo infortunada tumba de su hijo».

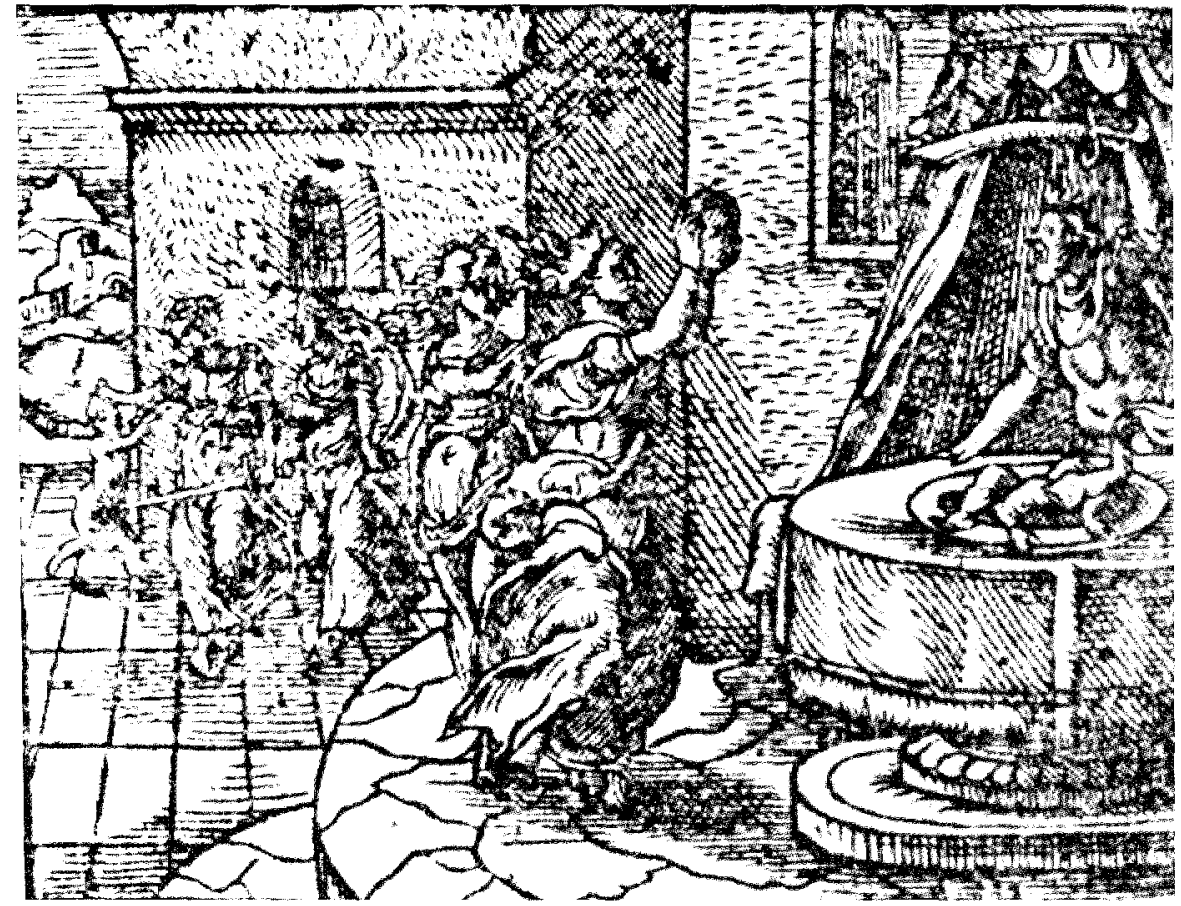

Fig. 5.

En este caso, la composición en diagonal de la escena que recorre tres pasos consecutivos de la violenta historia, se toma casi de forma absoluta de la fuente xilográfica de la edición de Las Metamorfosis de Amberes ilustradas por las estampas de Virgilio Solís (fig. 5). Al fondo las dos hermanas enmarcadas en un arco de medio punto (fig. 4), el cual constituye el foco lumínico de la escena, ejecutan su atroz venganza, mientras en primer plano, a la derecha, Tereo desenvaina la espada ante la terrible evidencia de la 
cabeza del hijo muerto que Filomena le espeta coléricamente. La imagen del mueble resulta aún mas espeluznante que el grabado, pues se han suprimido en esta ocasión toda clase de recursos anecdóticos de tipo constructivo, incidiendo en la intimidad del espacio preparado para la venganza, lo que produce en la escena un dramatismo todavía mayor.

La intencionalidad moral de este relato, en que los tres personajes se transforman en los subsiguientes pájaros: en abubilla, Tereo, en ruiseñor, Filomena y en golondrina, Procne, parece ser clara.

La escena es de mayores dimensiones que el resto de las metamorfosis reflejadas, y además ocupa el espacio central del escritorio, en ella obviamente existe una crítica a las consecuencias terribles que puede producir la pasión amorosa.

En los cajones laterales, que se encuentran dispuestos en sentido vertical, se representan distintas metamorfosis relatadas por Ovidio y plasmadas de forma sintética por nuestro artista. Todas ellas tienen un carácter moralizante y reflejan diferentes manifestaciones amorosas reprensibles tanto para los católicos como para los protestantes. Pasamos a comentarlos según la disposición actual, que no consideramos, por otra parte, que sea la adecuada, pues como se señala en una indicación en los mismos su ubicación real podría ser otra.

En relación con las imágenes representadas en los cajones del escritorio queremos señalar que consideramos que nuestro artista ha tomado como fuente gráfica las representaciones xilográficas de Virgilio Solís que aparecen en la edición de Las Metamorfosis impresas por Pedro Bellero en Amberes en 1595, en concreto nos referimos a las que el Museo Lázaro Galdiano conserva un magnífico ejemplar descrito por Palau ${ }^{23}$ como sigue: "Transformaciones de Ovidio en lengua española repartidas en quinze libros, con las allegorías al fin dellos y sus figuras, para provecho de los artífices dirigidos a Esteban de Ivarra secretario y del Consejo del Rey Nuestro Señor. (Escudo del impresor). En Amvers. En casa de Pedro Bellero. M. D. XCV. Con privilegio (1595), 18 h. 241 fols. 174 grabados en madera por Virgilio Solis. 45 marcos Baer. 4 libras 10 chelines Huth. En tafilete por Thompson, 10 libras 10 chelines Maggs Bors 1924".

Resulta muy evidente este uso de la fuente en el caso de la representación de Tereo, y en otras que más adelante comentaremos. Algunas de estas ilustraciones formarán parte del libro de emblemas Emblemata

23 Palau y Dulcet, Antonio; 1959 n. 207500. 
Nicolaireusneri 1.C. Partim Ethica et Physica...Francoforti, 1581, Imprenta de Jeremias Reusner. ${ }^{24}$

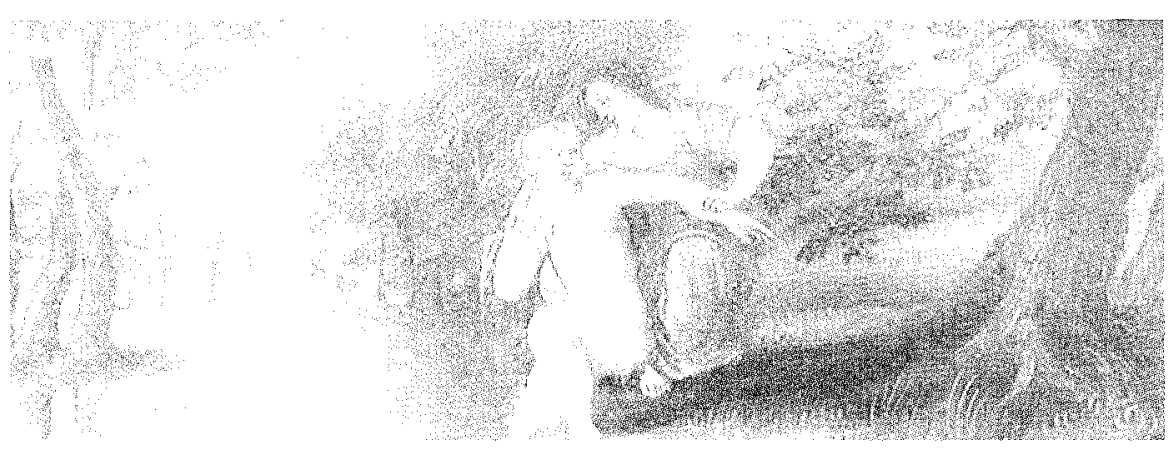

Fig. 6 .

Comienza la serie de ilustraciones tomadas de Las Metamorfosis de Ovidio con la representación de uno de los pasajes más sensuales en la narración ovidiana nos referimos al pasaje $V$ versos 271-415 del libro $V$ donde se da cuenta de la historia de Hermafrodito y Salmacis que Ovidio pone en labios de Lewcotoe, esta es la siguiente: Estando el hijo de mercurio y la diosa Citeria paseando, encuentra un lago de aguas cristalinas en el que habita la ninfa Salmacis, en su caminar es abordado por la ninfa que nada mas verlo sintió deseos de poseerlo. Se dirige hacia él y le llena de alabanzas, dándole a conocer su amor: Dichosa la mujer que se prometa contigo y para la que te dignes encender las teas nupciales. Si tienes una, sea el mio un placer furtivo; mas si no existe ninguna sea yo y penetremos en la misma cámara. ${ }^{25}$ El joven, que quiere rechazarla se siente sin embargo, tocado por el amor y aunque se muestra remiso y le pide que desaparezca, se despoja de sus vestiduras y prueba con su pie las frescas aguas. Es este el momento en que de forma casi literal se ilustra en nuestro mueble: atraido por la tibieza de las tranquilas aguas, se quita del tierno cuerpo las vestiduras. Mas entonces le agradó y Salmacis se abrazó en el deseo de su belleza al desnudo ${ }^{26}$. En el fragor del deseo Saimacis pedirá a los dioses que jamas llegue el día en que se separen y la concesión del mismo supone la pérdida de identidad sexual del joven, ambos quedan fundidos en un abrazo que hace que no sean

24 BARTSCH, A.: 1991, t. IX.2 (19). 1

25 Ovido Nason, P., 1992, tomo I pág. 135.

26 Ovidio Nason, P., 1992, tomo I pág. 137. 
dos sino una forma doble. Hermafrodito a su vez, eleva una súplica a sus padres para que todo aquel que se introduzca en las aguas de Salmacis sufra los mismos efectos. Según narra Leucotoe esta es la causa de la mala fama que tienen aquellas aguas.

El pequeño cajón (fig. 6) goza de un ambiente de cierta sensualidad, la escena se desarrolla en un frondoso bosque, donde aparecen fuertemente iluminadas las aguas del lago. En el centro de la imagen se encuentran las dos figuras con los atavíos y actitudes idénticas a las descritas, en una actitud que sin duda resalta el carácter seductor de la ninfa. Esta misma disposición de la escena es la que aparece en las obras de Crispin Van de Pass, en la de Goltzius o en la edición antuerpiense de las Transformaciones de 1595. Aunque debemos destacar en todas ellas un carácter mas narrativo, es decir en todas hay una referencia al desenlace de la historia, una alusión a la metamorfosis, mediante la representación de unas pequeñas figuras ya fundidas en el lago.

Al margen del carácter moralizante que pueda tener la escena en el desarrollo iconográfico general del mueble, parece oportuno destacar que tanto el relato literario como la piasmación pictórica emanan una cierta placidez, que sobretodo parecen destacar especialmente el arte de la fascinación, aunque la interpretación en este mueble sea la de criticar el hecho de sucumbir al deseo.

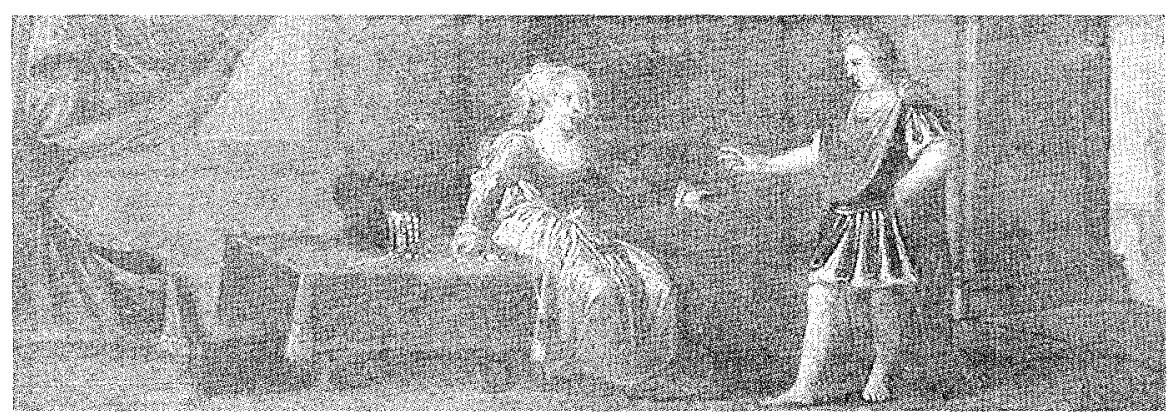

Fig. 7 .

La siguiente escena representada es la Historia de Céfalo y Procris. Esta es una de las escenas de más difícil identificación y se refiere a la leyenda de Céfalo y Procris, en concreto al momento en que el celoso Céfalo pone a prueba a su esposa haciéndose pasar por un extraño que intenta seducirla, aprovechando la prolongada ausencia del marido secuestrado. Es éste un tema poco frecuente en las representaciones figurativas, de la 
misma forma que lo es el de Mirra, o el de Neptuno y Ceneo. Un rasgo del autor que nos ocupa es la representación de escenas de amplia difusión junto a motivos mucho más crípticos y menos frecuentes en el mundo de las imágenes, esto es hasta cierto punto inevitable dada la cantidad de escenas a representar, pero no se explica únicamente por este motivo. En cualquier caso esta escena parece tener un significado más universal, el de la seducción por la riqueza material, la leyenda de Céfalo y Procris solo matizará esta significación.

Ovidio cede la palabra al propio Céfalo que cuenta a los hijos de Palante el dramático origen de la bella jabalina que luce. Les habla de su feliz boda con Procris, de la hermosura y virtud de ésta. Pero todo se tuerce cuando es raptado por la Aurora mientras se encuentra de caza, finalmente convence a la diosa de que le deje marchar pero no sin antes ser aguijoneado por la duda que provoca la raptora sobre su destino junto a Procris. EI azote de los celos sacude su alma así que pone en práctica una artimaña para probar la fidelidad de su amada: se introduce en Atenas y en su propia casa como un extraño e intenta seducir a su esposa ofreciéndole grandes riquezas a cambio de su compañía esa noche. Pero cedamos la palabra ahora al propio Céfalo: "¿Por qué voy a contarte cuántas veces su pureza de carácter rechazó mis intenciones?, cuántas veces me dijo: «Yo me reservo para uno solo; dondequiera que esté, reservo mis goces para uno solo" ¿ Para quién en su sano juicio no hubiera sido suficiente esta prueba de fidelidad? No me doy por contento y hurgo en mis propias heridas; una vez que, hablándole de entregarle una fortuna por una noche y al aumentar los obsequios, finalmente la obligué a dudar, exclamo mal fingidor: "iTienes delante un mal fingido adúltero, era tu verdadero marido; estás atrapada, desleal, siendo yo el testigo! " ${ }^{27}$. Este es el momento que refleja la escena del mueble (fig. 7), el del diálogo entre ambos, en concreto en el que ella cede y él adopta una actitud acusadora.

En el tercero de los cajones del lado izquierdo del mueble se representa la historia de Pigmalión que relata Ovidio en las Metamorfosis libro x 243297. La historia del legendario rey de Chipre que desengañado por las obscenas Propétidas vivía célibe, y que talla en marfil su propio objeto de deseo: Un dia talló felizmente con admirable talento, una escultura de níveo marfil, le dio una belleza con la que ninguna mujer podría llegar a nacer, y se enamoró de su propia obra ${ }^{28}$. Se refleja aquí uno de los temas fundamentales en el pensamiento platónico, la creación de la belleza ideal.

27 Ovidio Nason, P., 1992, tomo II, pág. 88.

28 Ovidio Nason, P., 1992, tomo I, pág. 184 


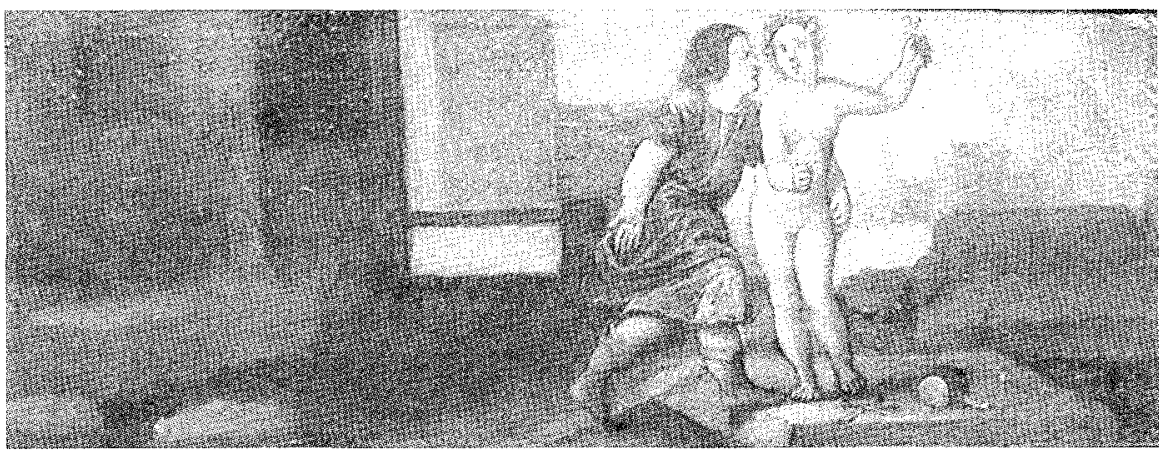

Fig. 8.

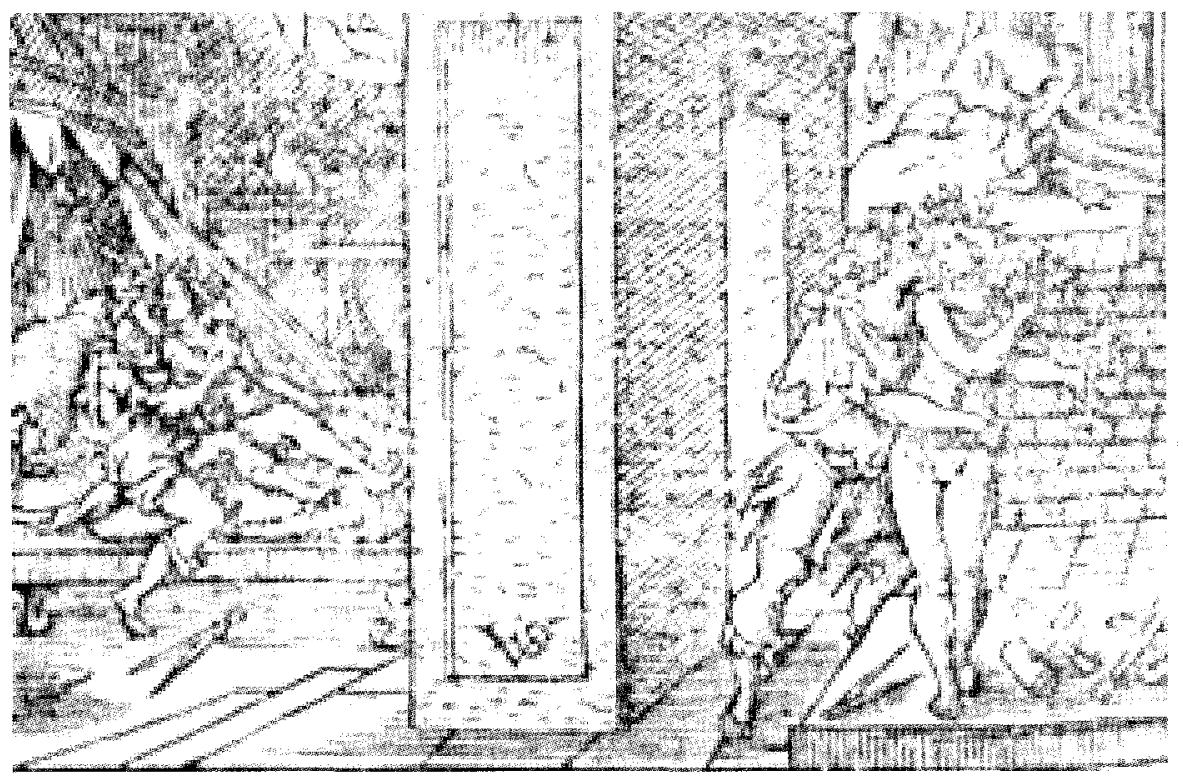

Fig. 9.

El artífice del mueble nos muestra ante un esenario arquitectónico a cuyo fondo se divisa una ciudad, al rey de Chipre acariciando su obra, la blanca escultura tiene a los pies los instrumentos de su hacedor y lleva en las manos los floridos ramos con los que Pigmalión solía decorarla. El instante reflejado dentro del pasaje ovídico es el siguiente: Pigmalión esta embelesado y en su pecho se enciende el amor por ese cuerpo falso, (...) Le da besos y cree que le son devueltos, le habla, le abraza y le parece 
que sus dedos se hunden en sus miembros cuando los toca...le lleva regalos de los que gustan a las muchachas como conchas, lisos guijarros, pajaritos y flores de mil colores ${ }^{29}$ La confusión de la realidad que produce el deseo es la síntesis de la representación del pasaje de Ovidio en nuestro artista. Aunque es semejante en la disposición de los personajes a la xilografía de Virgilio Solís (fig. 9), curiosamente la única de la serie de la edición de $1595{ }^{30}$ que aparece firmada con el acrónimo VS, la escena del escritorio resulta menos narrativa, más sintética (fig. 8). Solís parece interesarse por la adecuada identificación de la condición real de Pigmalión al que toca con la corona correspondiente y talla en la misma composición, mediante una segunda escena a la izquierda de la central, el desenlace feliz de la historia, en el que gracias a la intervención de Venus, Pigmalión conseguirá de los dioses el don de la vida para su amada Galatea. La Virgen sintió los besos que le daba y se sonrojó, y alzando hacia sus ojos y hacia la luz su tímida mirada, a la vez vio el cielo y a su amante ${ }^{31}$.

En nuestra opinión, nuestro artista se interesa por el concepto del amor a la belleza ideal, y por eso la representación de este pasaje es aquí tan sintética. El tema de la belleza ideal ha sido estudiado por Panofsky ${ }^{32}$ en su obra ldea. Se alude en este caso al amor inventado, y a la capacidad de transposición de la realidad que tiene el amor y se la relaciona con la creación del propio objeto de deseo y de la belleza ideal. En este acto creativo se sitúa, por otro lado, el origen del arte, por ello no faltan los atributos de la creación del escultor Pigmalión: el mazo, el escoplo y el cincel, en primer plano, son más importantes que la corona real. Es con ellos con los que el protegido de los dioses, to cado por la divinidad mediante la intercesión de Venus, logrará que la idea cobre vida.

El Cajón situado debajo del de Pigmalión ilustra la escena de uno de los amores relatados por Ovidio en el libro XIV de las Metamorfosis se trata de la historia de Vertumno y Pomona, uno de los temas mas reproducidos por la pintura de la segunda mitad del XVI y primera del xVII, muy especialmente en los Países bajos del norte $y$ en concreto en Amsterdam, centro del mercado artístico, en el que tienen una gran difusión las colecciones de grabados de las Metamorfosis realizadas por

\footnotetext{
OVIDIO NAsON, P.. 1992, tomo II, pág. 183.

OVIDIO NASON. P. 1595 y $156 \mathrm{~V}$.

OVIDio NAson. P. 1992. tomo II, pág. 184

PANOFSKI. 19,8. págs 116-148
} 
Crispin van de Passe (1560-1632) y por Hendrick Goltzius(1558-1616). Nuestro artista toma como modelo en este caso la obra de Rembrandt Ana y los Viejos que se encuentra en el Maurithius Museum de La Haya.

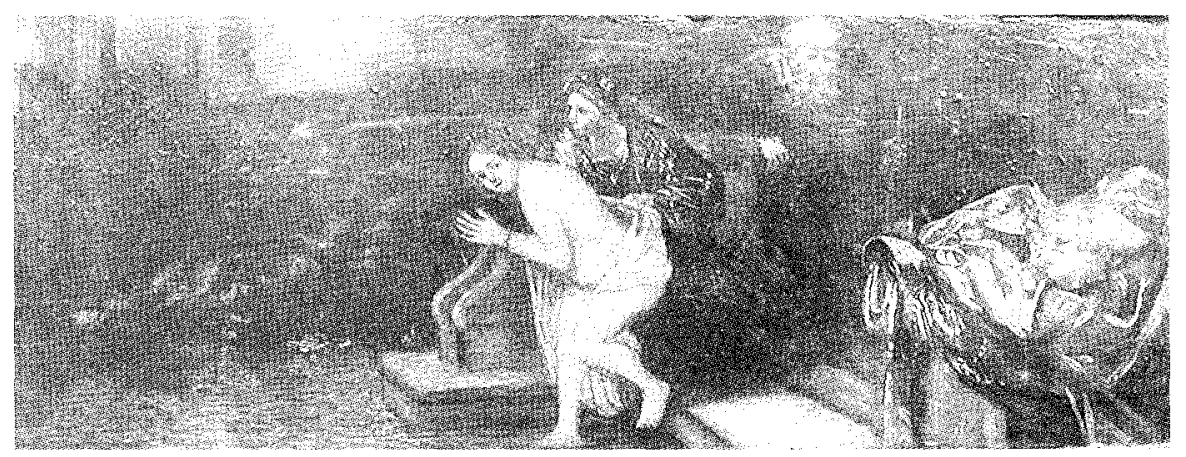

Fig. 10.

La historia de Pomona y Vertumno es un tema recurrente, protagonista de obras tan interesantes como la de Goltzius del Rijck Museum o la de Jan Brueghel de Velours del Louvre. Se trata no sólo de un tema alegórico amatorio, capital en las Metamorfosis, además es un tema de referencia económica en la sociedad holandesa que está desarrollando un importante comercio de flores como el tulipán, importado de oriente y cuya explotación se inicia en estas fechas. Es también éste el momento de desarrollo de la ciencia botánica. Se esta creando una metodología de estudio científico y descriptivo, esta metamorfosis que toma como escenario el jardín, así como las de Narciso, Dafne, o la misma Flora, funcionan en este ambiente social como referencias alegóricas.

Ovidio nos relata en el libro XIV la historia de Pomona, la Hamadríade con más pericia del Lacio, que cultiva como nadie los Jardines, no ama ella las selvas ni los ríos, sino el campo cultivado(...) Ésta es su pasión, este su afán, y por otra parte no tiene apetencia ninguna hacia el amor hacia ella se dirige Vertumno, dios de los vergeles y del vino quien, conocedor de su receloso cuidado del vergel toma múltiples formas para franquear la entrada: muchas veces empuñaba con rudas manos una aguijada, de manera que se hubiera jurado que acababa de desuncir unos novillos fatigados. Si se le provehia de una hoz [...] pescador si una caña, en fin muchas veces consiguió el acceso gracias a múltiples disfraces. ${ }^{33}$

39 Ovidio Nason, P.1992; Tomo II pág. 154. 
Es finalmente el aspecto de una agradable anciana el que le permitirá disuadir a la cauta ninfa, y disponerla favorablemente hacia sus amores, para ello emplea un discurso con dos alegorías: por un lado, la que describe frente a su vista el tronco de un olmo hermoso que soporta los magníficos frutos de una vid por compañera y por otra, la más significativa, el relato de la trágica historia de Ifix y Anaxerete, una tremenda historia de la que se deduce un trágico final de amores rechazados. Vertumno, en la piel de la anciana logra de la cándida Pomona una favorable disposición hacia sí que culmina en su transformación: Una vez que inútilmente expresó todo eso el dios encubierto de efigie de la vieja, volvió a ser joven y se quitó los atabios de la vieja, mostrandose a Pomona semejante a la figura explendorosa del sol cuando sale triunfante de las nubes que se interponian y vuelve a lucir sin que ninguna lo empañe, y se dispone a hacer uso de la fuerza, y la ninfa se dejó conquistar por el porte del dios y sintió a su vez la misma herida ${ }^{34}$.

En la representación del mueble que nos ocupa (fig. 10), se emplea, de forma casi exclusiva en el conjunto de representaciones metamórficas, una visión narrativa, casi literaria de la escena. Podemos contemplar en la misma imagen dos secuencias temporales y dos mensajes de la fábula. Por un lado Vertumno se nos presenta aquí como pescador portando una caña lo que alude a la capacidad transformista del dios, y por otro, en un momento posterior, tomando la apariencia de una cándida anciana haciendo gala de la capacidad persuasiva de su metamorfosis en vieja celestina que acecha a la joven mientras se dirige a su cercado vergel desde una escalinata. Esta concepción narrativa en la transcripción pictórica la encontramos sólo en la escena central de la cajonería de este escritorio. No es tampoco frecuente en otras representaciones del mito, lo que hace pensar en la existencia de una intención moralizante que tal vez aluda al uso del engaño para la persuasión amorosa.

La extraordinaria importancia que este pasaje adquiere dentro de las metamorfosis es evidente en el escritorio, conservado en el Museo de Artes Decorativas de Madrid donde se sitúa la escena en el centro del desarrollo general de la cajonería, tal vez utilizando como excusa el hecho de que este pasaje en sí mismo es pie de ulteriores narraciones, lo mismo ocurre en el mueble referido de la Casa Bonhams.

La historia de Pan y Siringe, que tan delicadamente refleja la pintura del cajón inferior izquierdo del mueble, la pone Ovidio en boca de Mercurio

34 Oviolo Nason, P.1992; Tomo Il pág. 155. 
cuando éste se encuentra en la empresa de liberarlo de la vigilancia de Argo, el héroe de los cien ojos. Mercurio tocaba para ello un instrumento fabricado de cañas ligadas, con el que intenta dormir, pero no lograba que esto ocurriera pues, mientras descansaban parte de sus ojos, Argos mantenía vigilante el resto. Maravillado por la música, el custodio pregunta a Mercurio cual es el origen del instrumento que toca y el dios le cuenta esta metamorfosis antes de darle muerte.

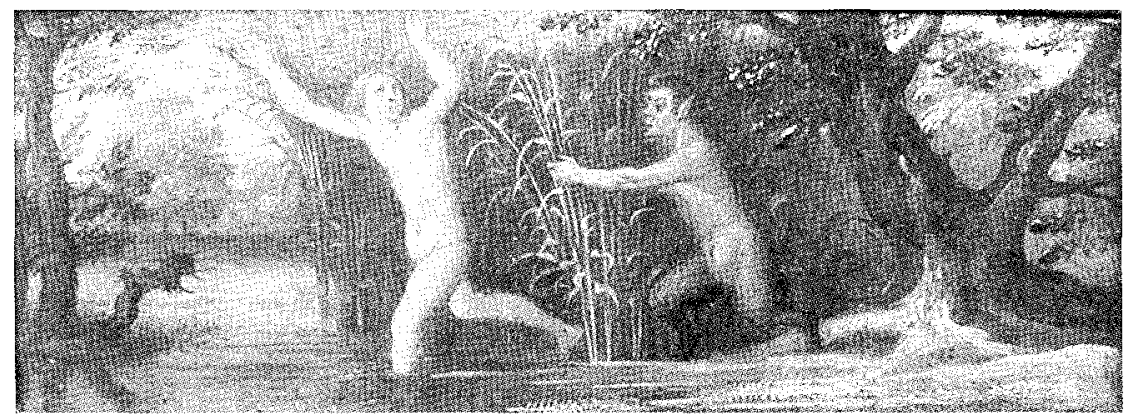

Fig. 11.

Siringe era una hermosa náyade que como Diana guardaba su virginidad del acoso de los faunos, un día que Pan bajaba del monte Liceo, la descubre y pretende conseguir su amor. La náyade huye y llega a la plácida corriente del río Nadón en el que suplica a sus hermanas las ninfas para que la transformen, de este modo, cuando Pan intenta abrazarla solo llega a tomar el brazado de cañas en las que se había transformado Siringe, al suspirar el dios sobre ellas el aire produjo un hermoso sonido, ante el que el dios dijo: iEsta será mi forma de hablar contigo! ${ }^{35} \mathrm{Al}$ concluir el relato se cerraron los ojos de Argos.

Las representaciones de la escena de artistas manieristas como Goltzius, Carel Van Mander y otros, reflejan la historia con una extremada referencia a la lubricidad del Dios. En este caso en nuestro escritorio, el relato adquiere de nuevo un carácter narrativo y sintético al tiempo, Siringe, casi en el centro de la escena, con los brazos en alto y la cabeza ligeramente vuelta hacia atrás observa el instante en el que Pan con patas de carnero, orejas puntiagudas y pequeños cuernos, abraza la metamorfosis de la propia náyade, la mata de cañas en que se ha convertido. La escena se desarrolla en

35 Ovidio Nason P. 1992 tomo l pág. 36. 
un sombrío bosque en el que sólo la luz del atardecer ilumina las calmadas aguas del Nadón que reflejan la luz en el cuerpo de Siringe. El frustrado Pan se encuentra en el área sombría de la escena.

Parece clara la exaltación de la virtud de la ninfa, que gracias a su metamorfosis preserva la virginidad, contra la lujuria del dios, y que se encuentra inscrita en el relato ovidiano de la metamorfosis. Tal vez estamos ante una exaltación de la virtud frente al amor mundano como parece claro que reflejan las múltiples representaciones pictóricas, que en ocasiones parecen implicadas en un discurso de sincretismo católico en el que se asimila a la figura de Pan la idea de la tentación. Sin embargo, no deja de sorprender el hecho de que en el relato ovidiano, sea esta historia el origen del instrumento que conseguirá dormir al custodio de Juno, la frase ¡Esta será mi forma de hablar contigo! lleva implicita una aceptación de la renuncia.

El cajón superior de la parte derecha del mueble está decorado con una escena del relato de Píramo y Tisbe, este relato tiene muchas similitudes con la posterior novela de amor griega. Es importante destacar, por otra parte, que no se tiene conocimiento de ningún relato anterior con esta leyenda, y que sin embargo tendrá una gran influencia en la Edad Media y posteriormente, por ejemplo, en el "Romeo y Julieta» de Shakespeare, lo que nos da una idea de la transcendencia de esta historia y de su permanencia como motivo literario y artístico hasta el período del autor de la decoración pictórica del mueble.

La historia de Píramo y Tisbe es la de un ardiente amor a pesar de la oposición de los padres de ambos, amor que acabará trágicamente con la

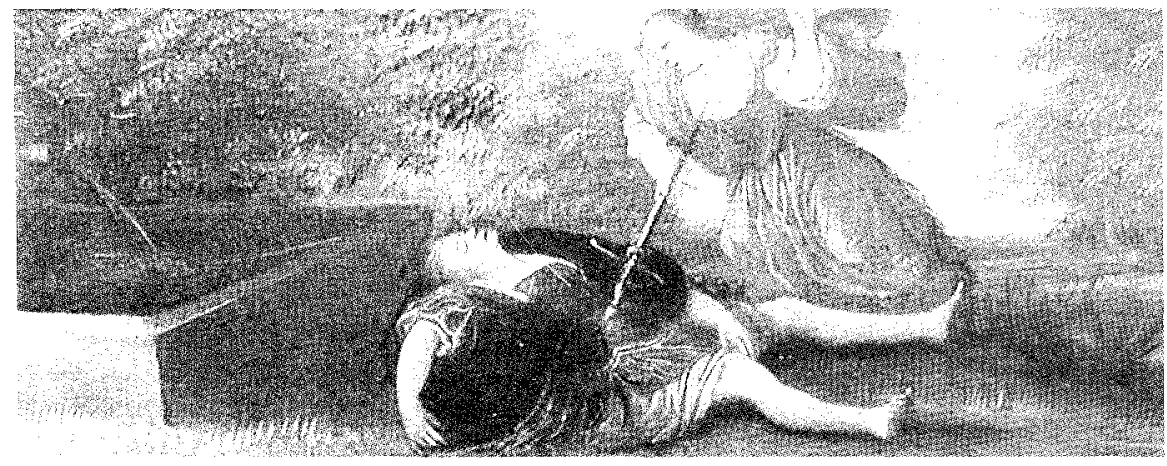

Fig. 12. 
muerte de los amantes debido a una serie de casualidades y malentendidos. Este afecto mutuo nace, nos cuenta Ovidio, por la vecindad de los personajes y habría llegado hasta el matrimonio de no ser por la voluntad contraria de los padres, de cuyos motivos no da cuenta el autor dejando así sin tratar prácticamente el tema de la legitimidad de la oposición paterna. Ovidio se centra mas bien en los devaneos amorosos de los personajes: desde los encuentros furtivos a través de la abertura de la pared que separa sus casas, hasta el trágico encuentro final en el tétrico y salvaje escenario del sepulcro de Nino. Es en este momento cuando se precipitan los acontecimientos dramáticos, una serie de infortunios que conduce al suicidio a los amantes.

El momento concreto que aparece representado en el mueble (fig. 12) es el instante en que Tisbe reúne valor para volver al escenario del encuentro y ve a Píramo expirando tras haberse suicidado al creer que su amante había sido devorada por los leones. Entonces toma la determinación de reunirse con su amado en el más allá y «... tras haber dispuesto la punta [de la espada] bajo su pecho, se lanzó sobre la espada, que todavía estaba tibia de muerte. ${ }^{36}$. Es éste prácticamente el final de la historia y solo le queda a la moribunda rogar a los dioses y a sus padres por la metamorfosis del árbol y el descanso eterno conjunto.

Pasaremos ahora a comentar la representación concreta que nos ocupa y sus relaciones con otras del mismo tema y el propio texto de Ovidio. En primer lugar destacaremos la transposición casi literal del texto de Ovidio en la representación del momento en que se sitúa la punta de la espada en el pecho y se abalanza sobre ella Tisbe. Además debemos añadir el fiel seguimiento de la descripción de Ovidio de la posición de Píramo tras su suicidio: «...y quedó echado en tierra boca arriba...» ${ }^{37}$, o la propia presencia de la fuente elemento fundamental en la narración ovidiana como centro magnético de las acciones de los personajes, de la misma forma que lo es el árbol o el velo de Tisbe. Señalaremos, sin embargo que existe una diferencia con el relato ovidiano tanto en la supresión de los componentes más sangrientes como en la anacrónica vestimenta de los personajes ataviados a la moda flamenca del siglo XVII.

La imagen del Museo de Artes Decorativas de Madrid es muy semejante a la nuestra, dejando a un lado las diferencias insalvables de 
calidad, en cuanto a la posición de Píramo, la de la fuente, o de la propia Tisbe.

Debajo de este cajón se ilustra la historia de Mirra que aparece ya en Paniasis (ver Apolodoro III 14,4), aunque con un tono cultural muy diferente al que le da nuestro autor, y tendrá una gran difusión desde entonces hasta la época del poeta romano.

Empieza el narrador Orfeo por advertir sobre lo terrible de los hechos contados y por evitar cualquier responsabilidad que de su exposición pudiera derivarse. Deja al lector la decisión de evaluar la verosimilitud de la historia y si la respuesta es positiva se cura en salud diciendo que también lo será la del castigo divino ejemplar, si, en cambio, la decisión es la contraria no hay ningún problema. Incluso dice: "Crimen es odiar a un padre; este amor es un crimen mayor que el odio." 38 Estamos pues ante un nuevo episodio de justicia divina que castiga los vicios y que se acomoda perfectamente en el programa iconográfico del mueble.

Mirra es nieta de Pigmalión y es el relato que sigue en la colección de metamorfosis al del rey escultor, hay por tanto varios lazos que relacionan ambas historias y que justifican la presencia de ambos. La hija de Cíniras es pretendida por numerosos jóvenes orientales pero en su corazón palpita un deseo prohibido; ella desea a su padre. Se da cuenta de lo condenable de sus inclinaciones pero al mismo tiempo busca razones para justificarlas, se debate entre ambos extremos, incapaz de hallar una solución. Mirra encuentra paralelismos a la naturaleza de su deseo en los mundos animal, divino y humano y lamenta que el azar haya determinado estas coordenadas geográfico-temporales que culpabilizan su deseo. Pero al mismo tiempo ama a su padre por su virtud, la misma que retiene la consumación de sus pretensiones: la paradoja está servida y Mirra solo encueritra una salida, la muerte. Pero la aparición de una tercera figura impide que se quite la vida, se trata de su nodriza que guarda numerosas similitudes con la figura de la celestina. Ella le permitirá llevar a cabo sus deseos mediante el engaño al procurar al padre una anónima amante nocturna que no es otra sino la propia Mirra. Cuando el padre acepta, aún sin saberlo, el amor de su hija, su figura se torna vil y mezquina (pues ha traicionado a su madre y a los dioses). La degeneración del padre acompaña a la de la hija. Es la figura de la celestina la que lleva a Mirra más allá de la contradicción en la que estaba

ov Ovioro, 1994. tomo II, pág. 186. 
bloqueada, ella no habría dado ese paso sin la intervención de la vieja. La diferencia moral entre ambos está en que el padre es conducido con engaño y la hija es consciente de lo que hace. El padre reaccionará virulentamente cuando descubra que es su hija el objeto de sus devaneos, en el culmen de su corrupción encontrará un resquicio de la virtud que antes le definía. Cuando desaparece el engaño vuelve la paradoja inevitablemente haciéndose insoportable a la «heroína». La muerte ya no será un final tranquilizador, solo podrá continuar existiendo a través de la metamorfosis que la situará en un terreno intermedio entre la vida y la muerte. Desde allí nos recordará eternamente su historia, sus errores y su castigo por los dioses a petición propia.

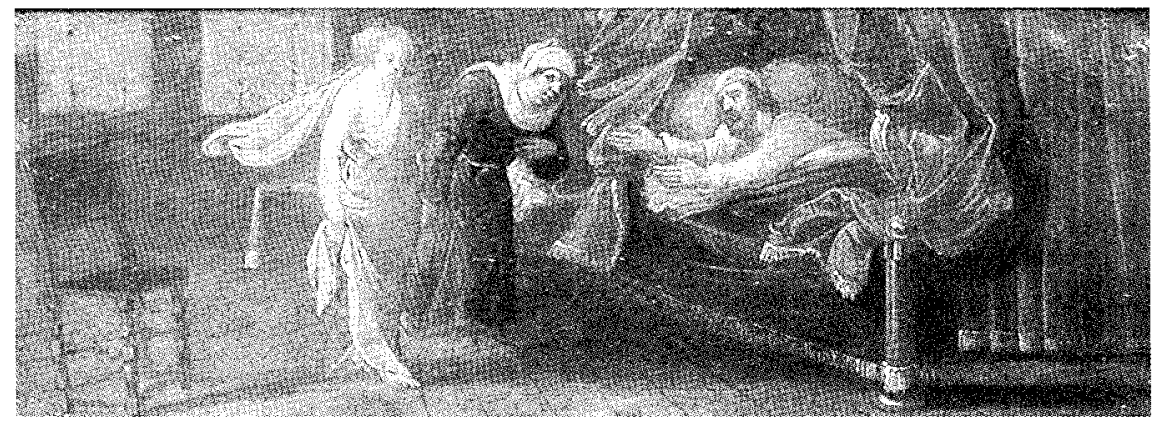

Fig. 13.

Esta representación nos muestra el instante en que «la anciana conduce con su mano a la que duda y, al entregar a la conducida al alto lecho, dijo "Recíbela, Cíniras, ésta es tuya" y unió los cuerpos malditos. ${ }^{39}$ Es por lo tanto la transposición literal de un instante de la narración ovidiana. En este caso no hay por tanto un sincretismo temporal como en otras escenas excepto por la aparición de elementos contemporáneos como la silla, la cama o las ventanas que le sirven al pintor para actualizar los hechos narrados y al mismo tiempo su discurso moralizante. En esta escena no refleja el artista ni el castigo de acciones tan «vergonzantes" ni las vacilaciones de Mirra que camina decidida y firme aunque con pasos cortos, la cabeza gacha y un ligero rubor que recorre sus mejillas, indicio de su vergüenza. Mientras tanto su padre la llama con los brazos abiertos, el autor solo parece interesado en el momento de la

39 Ovidio, 1994, tomo Il, pág. 190. 
entrega amorosa, el más criticable, el pintor no muestra las dudas de Mirra o su castigo, haciendo la misma elección que en el resto de las escenas del escritorio.

La celestina ocupa el centro de la composición reflejando así el carácter primordial de su figura en el relato ovidiano, meridiano en cuanto a que aparece en la mitad del relato y en cuanto es el motor de la acción. Se sitúa además entre la hija y el padre como intermediaria entre ambos, ilustrando así gráficamente lo que hemos dicho respecto al texto ovidiano.

La figura paterna aparece en actitud de reclamo absoluto como en el relato en el que el padre da un giro brusco en su valoración moral al aceptar ciegamente la amante que le ofrece la celestina.

Si comparamos la representación del mueble con la del grabado de Virgilio Solís encontramos numerosas similitudes compositivas aunque invertidas como es lógico pero también una diferencia fundamental que está en la valoración de la figura paterna que parece más la víctima de un

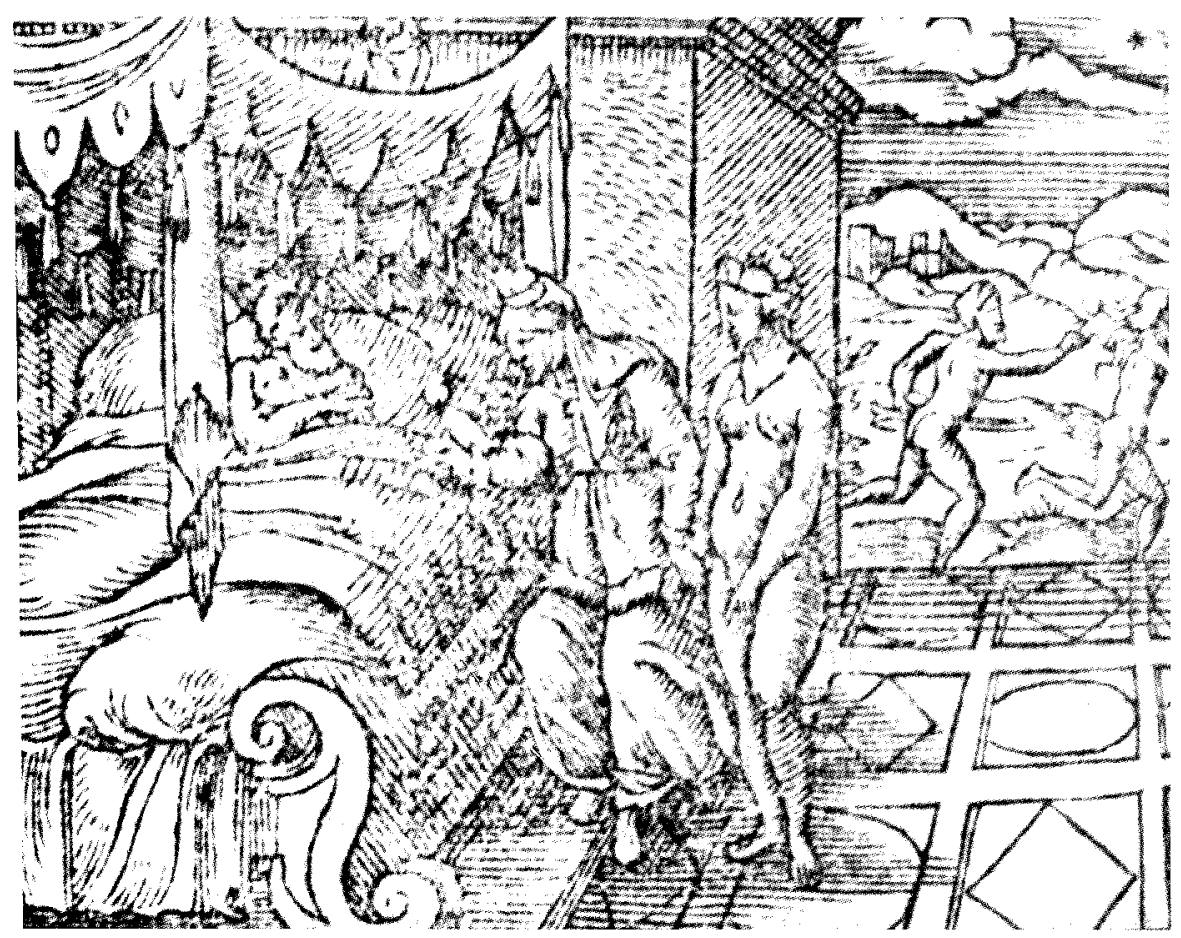

Fig. 14. 
engaño que un hombre conspicuo, la figura del patriarca sale así menos malparada. El tema del que nos hablan ambos artistas parece diferente, mientras Solís nos habla de un engaño, el autor del mueble nos habla del vicio condenable del incesto.

Demos la palabra ahora a la interpretación de las Metamorfosis que venimos comparando con las imágenes y el texto ovidiano: «La moralidad desta fabula pone Natal comité, diziendo: efta fabula declara lo que es la confciencia propria de los peccados cometidos contra Dios, y quantos golpes de miedo, y de verguença padescen los peccadores antes de poner por obra su mala intencion y quales son las promesas y votos de los hombres, quando pretenden alcançar de Dios algo que no es honesto, por que acabado de coseguir lo que ardentissimamente desseauan, al punto fe les abren los ojos del entendimiento, $y$ entienden quan feas torpes, y fuera de tino eran las cosas que con tanta efficacia pidieron ante la confecucion de las quales fe tenian por miserables e infelicissimos, siendo alcançarlo, pues es offensa de Dios, la misma infelicidad y miseria, Pedro Bembo tiene por opinión que la fabula de los amores de Myrha y su padre Cyniras fue fiction para darnos a entender a quales despeñaderos e infortunios vienen los que resisten al amoroso fuego." ${ }^{40}$ La primera de las interpretaciones es más confusa pero pone el acento como Solis en la figura paterna como metáfora de Dios, mientras que la de Pedro Bembo es más cercana a la lectura del texto ovidiano que hace nuestro artista.

La temática de Danae y la lluvia dorada se desarrolla en el siguiente cajón (fig. 15) y es muy habitual en el mundo de la pintura como atestiguan las versiones de il Corregio, Tiziano, Tintoretto y Rembrandt entre otros.

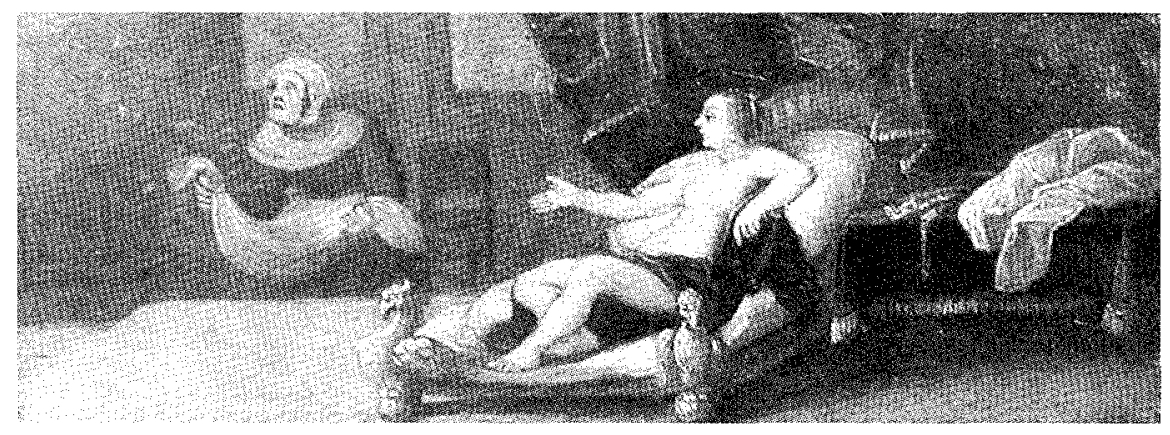

Fig. 15.

40 OVIDIO, 1589, Anotaciones sobre Ovidio pág. 200. 
La fuente de Ovidio en esta ocasión no nos será muy útil ya que solo hace una pequeña referencia a esta historia. Más explícitos serán los argonautas de Apolonio de Rodas: «Un oráculo habia predicho a Acrisio, rey de Argos, que su hija, Danaé, tendría un hijo que lo mataria. Entonces, Acrisio la encierra en una habitación de bronce bajo tierra. Pero Zeus, que la amaba, transformado en lluvia de oro, entra por el tejado y seduce a Danaé. De esta unión nació Perseo". Encontramos varios aspectos interesantes en esta narración desde un punto de vista iconográfico. En primer lugar la referencia a un oráculo que predice a un rey que un descendiente le mataría, como en el caso de Cronos, refiriéndonos al afán de mantener el poder aún a costa de la familia: el deseo de poder, la tiranía es otro de los vicios condenables en un gobernante. La burla del encierro de Danae por Zeus indica la omnipotencia divina, la omnipresencia del amor divino, y su transformación en lluvia del más precioso de los metales, siempre identificado con la divinidad, nos explica la belleza divina, su esencia lumínica, su incorporeidad. Por otra parte la manifestación de Dios es múltiple ya que en unas ocasiones está prohibida y es dañina para el hombre, mientras que en otras, como en este caso, es maravillosa para el hombre o la mujer. Aquí parece denotar la seducción por lo material, al igual que en el caso de Céfalo y Procris, como atestigua la mano extendida y complaciente de Danae y la presencia de la vieja que intenta recoger las monedas en que se materializa la metamorfosis del dios. Nos encontraríamos pues con una nueva crítica de un vicio, el materialismo, o la asociación de la imagen divina con la ostentación, una de las críticas más frecuentes de los protestantes hacia el papado católico.

Pasemos ahora a comentar la imagen concreta que nos ocupa, están representados de nuevo muebles de la época como la silla, la cama, la mesa y las ventanas que actualizan el mensaje como ya hemos comentado. Las águilas que se yerguen soberbias en las patas de la cama son una clara referencia a Júpiter, y en concreto a una de sus metamorfosis. La figura de la vieja materialista es ajena a los relatos clásicos y explicita de forma más redundante el discurso sobre lo condenable del materialismo. El gesto complaciente de Danae confirma este discurso y nos remite de nuevo a la idea de seducción por la riqueza. Este tema se presta a diferentes interpretaciones según los elementos iconográficos que se pongan en juego, pero en este caso el sentido es claro y es el que ya hemos referido.

Recurramos de nuevo al texto del Licenciado Pedro Sánchez de Viana para que nos muestre el otro punto de vista, el cristiano: "Esta fabula toca a interpretant Hicronimo, y Horacio, y significa el encerramiento de 
Danae, y que no obstante tanto recato guarda, lupiter convertido en gotas de oro la stupresse, que las dadivas (como dizen) quebrantan peñas, $y$ que al oro no ay casa fuerte: pues no se halla puerta cerrada, ni muro tan firme, y seguro en esta fabula se encierra secreto de Astrología. Porque quando lupiter es señor del nascimiento de alguno, le inclina a amor honesto: pero de tal manera, que si se junta a otro Planeta inclina a amar cosas de la naturaleza de aquel con quien comunica, y ansi estando en conjuncion con Mercurio influye amor util. Porque Mercurio es protector de la hazienda, y por ello dizen que lupiter amo a Danae, mudado en gotas de oro. Pues la liberal distribucion de las riquezas hace ser el hombre amado de los necessitados, que las reciben" ${ }^{41}$. El oro abre muchas puertas por tanto, pero también explicita el amor util, del casamiento por conveniencia, otro de los vicios criticables desde el punto de vista de la época. La visión cristiana también es critica en consecuencia pero desde un punto de vista diferente.

En el interior de una estancia a la flamenca, decorada con mobiliario de fines del XVI-principios del XVII, se desarrolla la escena de los adúlteros amores de Marte y Venus (fig. 16). A la derecha, en un tálamo revestido de rojos cortinajes se abrazan los amantes, a sus pies descansan la espada y el escudo de Marte abandonados. Las vestiduras de Venus se apoyan en una mesa, mientras Eros juguetea con el casco de Marte.

La escena se desenvuelve en una atmósfera de apasionada armonía en la que los rojos cortinajes que caen del dosel sobresalen extraordinariamente, prolongando la traviesa actitud en la que juega el pequeño Amor.

El relato de los amores de Marte y Venus aparece en la Odisea Homérica libro VIII 266-365 y también en Ovidio aunque de forma muy breve en ambos casos. Es frecuente la representación del episodio en el que los amantes son sorprendidos por Vulcano y expuestos a la burla del resto de los dioses. Para ello, el esposo de Afrodita, alertado por el Sol del adulterio, había forjado una red de invisible mecanismo que atrapara a los amantes en el mismo lecho. Sin embargo no parece ser éste el momento que interese a nuestro pintor sino la representación alegórica de los amores de los dioses. El gesto juguetón de Eros que se está probando el casco de Marte y la espada abandonada a los pies del abrazo, parecen mas bien una referencia a la capacidad civilizadora del amor, totalmente presente en el Ars amandi de Ovidio como ha señalado Ruiz de Elvira en su libro

41 Ovidio, 1589, Anotaciones sobre Ovidio pág. 96. 


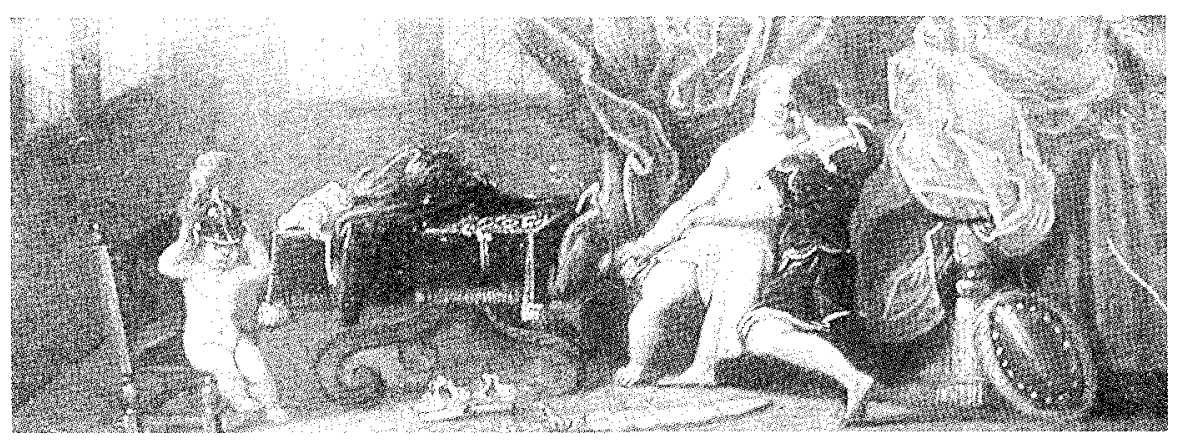

Fig. 16.

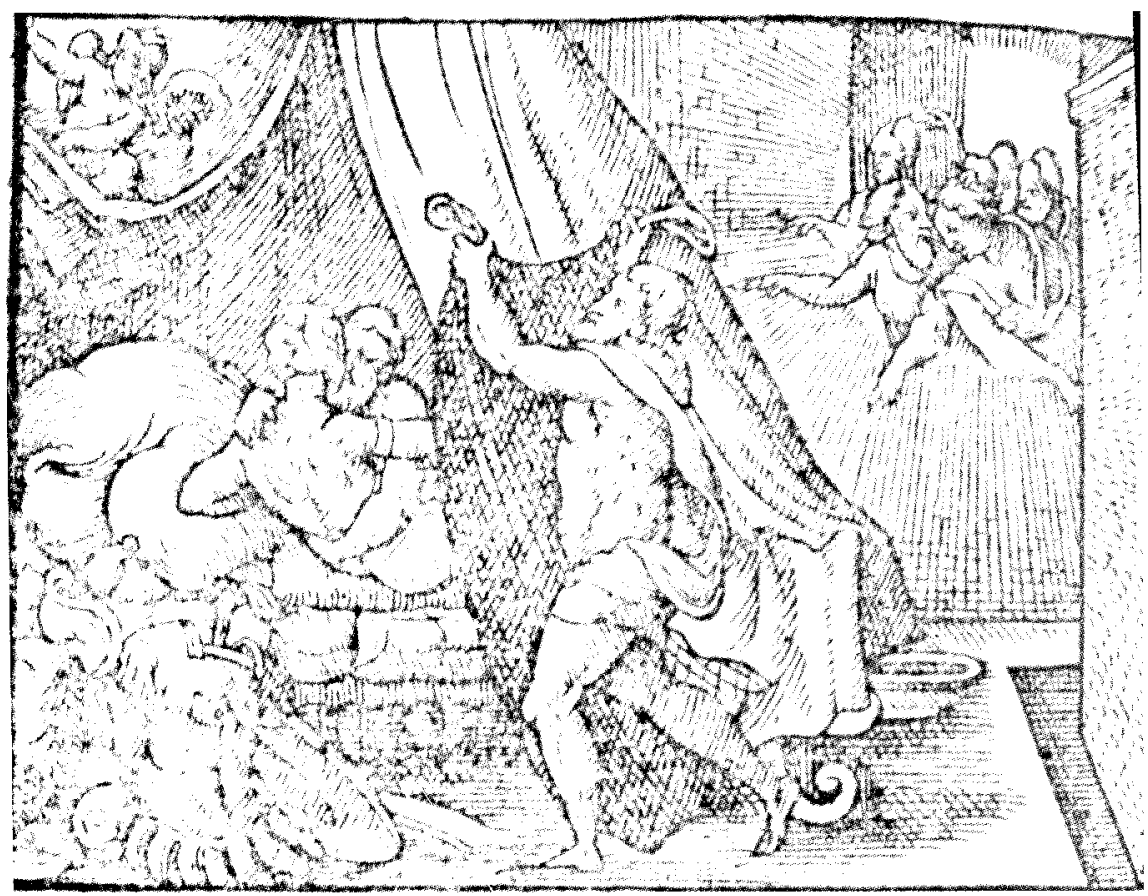

Fig. 17.

sobre la mitología. No olvidemos que de estos amores adúlteros nacerá Harmonía. En este caso el sentido de la alegoría es otro: la burla que hace Eros de los atributos de Marte nos remite a la obra de Platón «La República 
o de lo Justo", donde el gran filósofo expulsa al amor vulgar de su Estado ideal al considerarle una nefasta influencia para la formación de sus ciudadanos-guerreros ${ }^{42}$.

Sobre este relato reflexiona Sánchez de Viana del siguiente tenor: "Ansi que la luxuriosa Venus se quiere enamorar del ardiente Marte, de donde los astrologos ponen grandisima amistad entre estos dos planetas y dicen que Venus corrige toda la malicia de Marte con su beningno aspecto, y que excediendo la luxuria por la mission de ambos a dos: el sol que es la clara razón humana, los acusa a Vulcano dando a conoscer que por aquel excesso el calor natural viene a faltar" ${ }^{43}$. Aparte de las referencias astrológicas, este texto cristiano refleja una condena de los hechos semejante a la calvinista.

La escena que se desarrolla en el último cajón tiene una complicada atribución temática. La identificación del dios de los mares, Neptuno, es evidente por la aparición del carro tirado por los caballos saliendo del mar a la izquierda de la escena y en un segundo plano, la fisonomía de la figura es también característica de esta divinidad. Aquí acaban los signos que evidencian de una manera muy clara y llamativa el tema que enuncia la representación pictórica. Está claro, por tanto, que se trata de uno de los amores de Neptuno, pero ¿cuál? Los amores de este dios no tienen un gran desarrollo en "Las Metamorfosis» de Ovidio lo que complica más la cuestión. Solo el descubrimiento del grabado de Solis que tiene un gran paralelismo formal con la imagen que nos ocupa, nos permitirá la identificación de la escena.

Al mismo tiempo este descubrimiento nos permite identificar otros signos del relato como son: la ciudad que aparece al fondo, la situación costera en que se desarrolla la escena y el gesto de rechazo de la pretendida por el dios. Se trata del relato que narra el encuentro de Neptuno y Ceneo.

Es esta una composición diferente a las anteriores en cuanto que los personajes se sitúan ligeramente desplazados y dirigiéndose hacia la izquierda, en movimiento contrario al de los personajes del cajón situado a la misma altura en la otra columna de cajones (el que representa a «Pan y la ninfa Siringa»), en este sentido es muy interesante observar la combinación del sentido de los movimientos de las diferentes representaciones

42 Platón, 1991, La República.

43 OvIDIO, 1589, Anotaciones sobre Ovidio pág. 81 v. 
pictóricas del mueble: encontramos tantos movimientos hacia los laterales, como movimientos enfrentados hacia el centro que se equilibran. Así las puertas laterales representan movimientos contrarios: la de la derecha hacia la izquierda y la de la izquierda hacia la derecha del espectador, ambas nos dirigen la mirada hacia el centro, recurso muy barroco y que articula las diferentes escenas en una dinámica que solo se detiene en el reino soberano de Venus y el Amor de composición triangular y, por tanto, estática en su perfección.

En esta composición el espacio central lo ocupa en último plano la ciudad como en el grabado. Entre el primer y el último plano se sitúa un tercero intermedio ocupado por el carro del dios que sale del mar, es ésta la única escena en que se produce un escalonamiento tan gradual de la profundidad espacial que racionalizará su desarrollo. Si comparamos esta representación con la del grabado ya comentado encontramos algunas diferencias: la más destacable es la aparición de un gran peñasco situado en el grabado que centraliza el espacio, pero sin duda la variación más significativa desde nuestro punto de vista se refiere a la actitud de Ceneo que mientras en el grabado parece consentir a los deseos del dios marino, en la escena del mueble intenta zafarse del abrazo de Neptuno al tiempo que su rostro refleja una profunda angustia. Este importante cambio se puede interpretar como la representación de la virtud de la castidad como en el caso de la representación del cajón de la misma altura de la otra parte del mueble ("Pan y la ninfa Siringe» del que ya habíamos establecido un paralelismo formal con la escena que nos ocupa). En ambos casos el personaje femenino huye o se resiste del acoso irracional de un dios al que finalmente no consigue eludir en una referencia a la predestinación de algunos hombres hacia el vicio, que encaja en el discurso calvinista.

Otra diferencia significativa en relación con el resto de las escenas es la de su gran iluminación, este rasgo de la representación parece ir relacionado con el desarrollo del espacio, en este enorme espacio nada obstaculiza el paso de la luz, no sitúa un plano opaco detrás de los personajes que les resalte y que limite el desarrollo espacial a los lados como en otras escenas, espacio vacío y luz, rasgos de la divinidad en la última escena de la serie de cajones en un desarrollo de izquierda a derecha y de arriba hacia abajo como corresponde al sentido clásico de lectura en la civilización occidental. Las figuras nos llevan fuera del círculo de representaciones de los cajones como en un final cinematográfico, pero el movimiento de los personajes de la puerta derecha nos devuelve hacia la puesta en escena del universo metamórfico ovidiano: no podemos escapar de su discurso cíclico. 


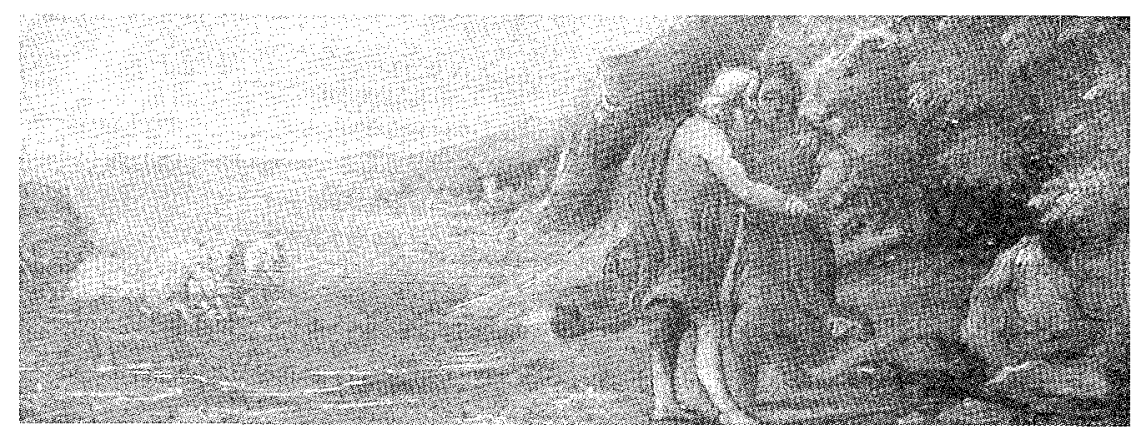

Fig. 18.

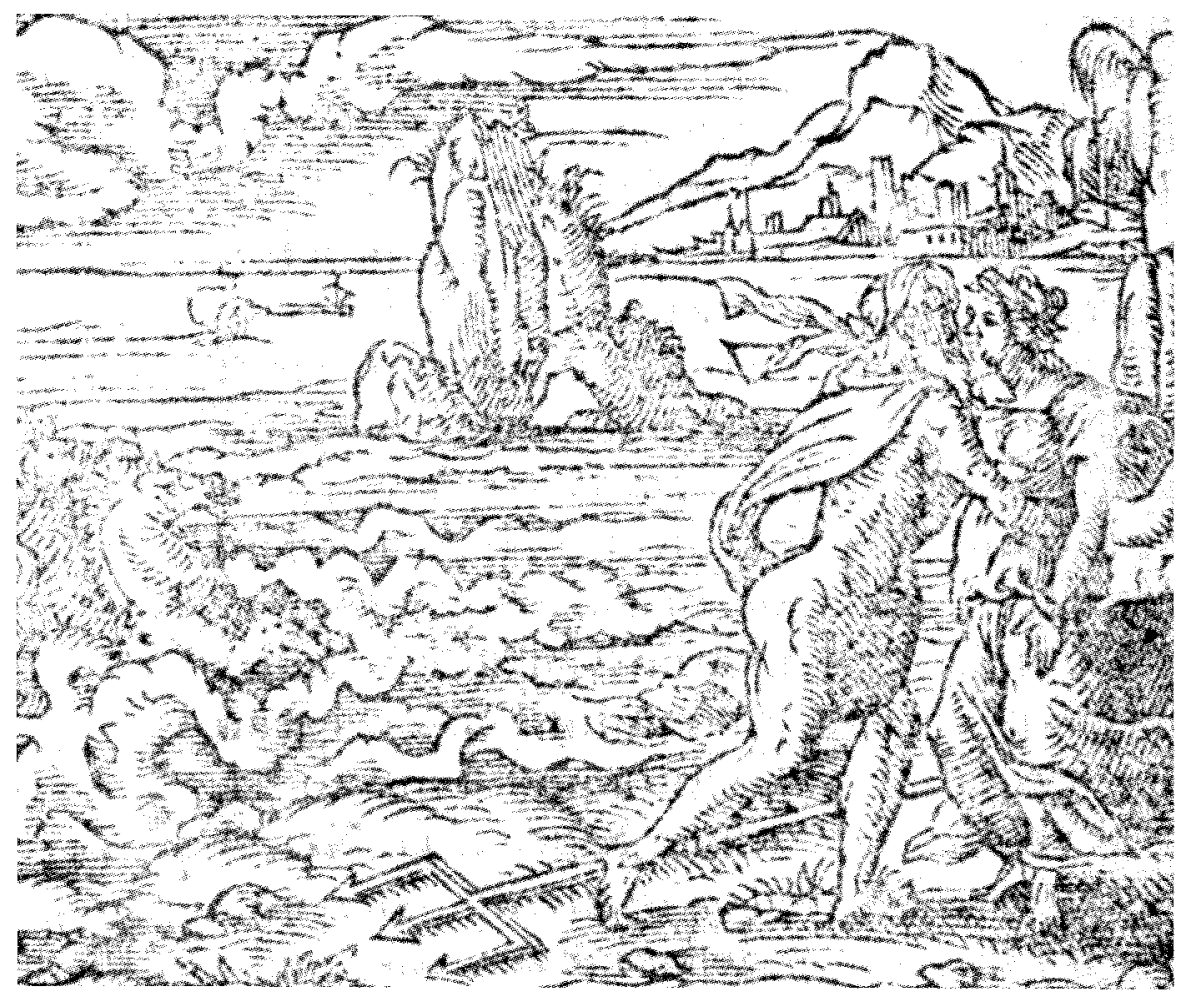

Fig. 19. 


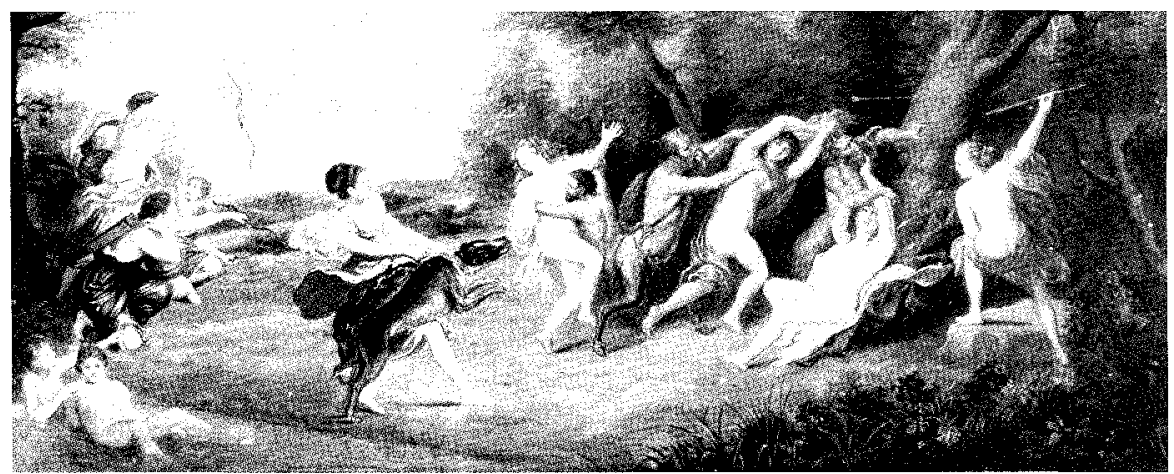

Fig. 20.

Este escritorio está coronado con una tapa también decorada con pinturas. En este caso aparece una copia parcial de "Ninfas y Sátiros» que Rubens pintara para el Pabellón de la Torre de la Parada en 1639 y que se encuentra actualmente en el Museo del Prado. Sin embargo esta violenta escena aparece contemplada por dos figuras en el ángulo inferior izquierdo que suscitan importantes dudas respecto a su adscripción estilística a este momento que por el contrario nos parecen bastante posteriores tanto desde el punto de vista icónico como estilístico, ello nos hace pensar en la posibilidad de que esta pintura de la tapa sea una reposición de una anterior, pero no tenemos aún suficientes datos para asegurarlo. En este caso como en otros muchos, sería de grandísimo interés la localización del mueble mencionado por la profesora Monique RiccardiCubitt en su obra "Le Cabinet" del que ya hemos hablado.

En cualquier caso la temática que reproduce encaja perfectamente en el discurso pictórico del mueble, en cuanto es una clara referencia al asalto de la virtud por los vicios.

Estamos en definitiva ante un escritorio realizado en Amberes en la primera mitad del siglo XVII para una burguesía comercial protestante en el que se realiza un magnífico ejercicio de sincretismo cultural que recoge argumentos de la tradición clásica y renacentista, tanto literaria como filosófica, para articular un complejo sistema de valores morales propios del calvinismo.

Esperamos que la comparación estilística y formal con el otro mueble similar, ya comentado, nos permita realizar una adscripción de autoridad mucho más precisa en el futuro, al tiempo que desvele algunos aspectos sobre el discurso moral del escritorio del Lázaro. 


\section{BIBLIOGRAFÍA CITADA}

Aghión, I. et al. (1944): Guía iconográfica de los Heroes de la Antigüedad, Madrid, Alianza.

APULEYo, Luico (1998): El asno de oro, Metamorfosis, Madrid.

BARTSCH, Adam (1987): The Illustrated, German Master of the sixtcentle century, tomo XIX, parte I.

Calvino: Instituto Christianae Religionis.

Castellanos, Casto (1986): "Escritorios europeos en el Museo Lázaro Galdiano»; Goya n.* 193-195, Madrid.

FiCINo, Marsilio (1986): De amore: Comentario a «El banquete» de Platón, Madrid, Tecnos.

JOHNSTON, Palema y SCRIBNER, Bob (1992): La reforma en Alemania y Suiza. Madrid.

LUTERON, Martín (1990): Escitos políticos, Madrid, Tecnos.

OVIDIO Nasón. P. (1589): Anotaciones sobre los quince libros de las Transformaciones por Sánchez de Viana, Valladolid.

Ovidio NASÓN, P. (1595): Las Transformaciones de Ovidio en Lengua Española. En Anvers, en casa de Pedro Bellero.

OVIDIO NASÓN, P. (1992-1994): Metamorfosis. Texto y traducción por Antonio Ruiz de Elvira (contiene: Volumen I Lib. I-V; Volumen II Lib. VI-X; Volumen III Lib. XI-XV), Madrid, Consejo Superior de Investigaciones Científicas.

PALAU DULCET, Antonio (1959): Manual del librero hispanoamericano, Barcelona, Librería Palau, tomo XII.

PANOFSKI, Erwin (1989): ldea, Madrid, Cátedra.

PLATÓN (1982): El Banquete o del amor, Fedón o del alma. Barcelona, Planeta.

PLATÓN (1991): Diálogos, México, ed. Porrua.

RICARDI CuBIT, Monique (1993): Un art europée, Le Cabinet de la renaissance a l'époque moderne. Paris.

Rodriguez Santidrian (1994): "Marsicilio Ficino" en Humanismo y Renacimiento, Madrid.

THORTON, Peter (1978): Seventeenth-Century Interior Decoration in England, France and Holland, Yale. 
